\title{
Is It Ritual? Or Is It Children? Distinguishing Consequences of Play from Ritual Actions in the Prehistoric Archaeological Record
}

\author{
by Michelle C. Langley and Mirani Litster
}

This paper identifies a significant interpretive issue for prehistoric archaeology: distinguishing adult ritual actions from the activities of children in the archaeological record. Through examining ethnographic accounts of recent huntergatherer children and reconsidering archaeological patterns and assemblages in light of these data, we explore how the results of children's play can be - and likely have been - misinterpreted by archaeologists as evidence for adult ritual behavior in prehistoric contexts. Given that children were a significant component of past hunter-gatherer (and other) societies, the fact that the material components of their activities overlap tremendously with items used in adult rituals must be routinely considered by archaeologists if we are to reconstruct robust understandings of past peoples all over the globe.

Do footprints in deep caves represent ritual visits, or simply the bravado of youngsters? . . Is the positioning of a bear skull part of a mystical rite, or the result of a child playing with it? (Bahn 2012:344)

Applying the adage "it's ritual" to any object or pattern in the archaeological record that cannot be explained by economic or technological activities has long been commonplace in archaeology. And while in many cases such interpretations may be correct, we researchers routinely overlooked another agent that equally, and perhaps more frequently, can be responsible for such discoveries - children.

Children were a significant part of Paleolithic - and other prehistoric - societies. Indeed, it is probable that children constituted the largest group of individuals in these communities (Chamberlain 1997), perhaps constituting as much as $40 \%$ of the population (Wobst 1974). Despite this fact, it was not until 1989 that researchers turned serious attention to identifying and investigating children in the archaeological record-a situation that was found not to be unique to deep-time contexts but instead riddled throughout archaeology in general. Two commonly held ideas continued to perpetuate this circum-

Michelle C. Langley is an Australian Research Council (ARC) Discovery Early Career Researcher Award (DECRA) Research Fellow in the Australian Research Centre for Human Evolution at the Environmental Futures Research Institute of Griffith University (170 Kessels Road, Nathan, Queensland 4111, Australia [m.langley@griffith.edu.au]). Mirani Litster is a Postdoctoral Researcher in Archaeology and Natural History at the School of Culture, History, and Language in the College of Asia and the Pacific at the Australian National University (Fellows Road, Acton, Australian Capital Territory 0200, Australia [mirani.litster@anu .edu.au]). This paper was submitted 23 IV 17, accepted 16 VIII 17, and electronically published 12 IX 18. stance: (1) that children are not important because their activities do not make significant contributions to communities and societies as a whole and (2) that children are unknowable in nonmortuary contexts, as their behavior leaves few material traces - their story is archaeologically silent (Baxter 2005b). In response, numerous researchers pointed out that the first notion was largely based on Western-centered ideas of childhood that frequently deny the diverse roles children hold in different cultural settings (e.g., Baxter 2005a; Bugarin 2005; Kamp 2001; Sofaer Derevenski 1994a, 1994b, 1997, 2000), while the second is countered by the logic that if children are a significant presence in all human groups, it should be expected that they should correspondingly have influenced the creation of the archaeological record (Chamberlain 1997). Despite these inroads, the main thrust of academic research remains focused on utilitarian issues such as subsistence strategies and technological innovation, thus relegating children to being an interesting but not particularly accessible nor useful aspect of the past. This unwillingness to investigate children has effectively erased genuine traces of children from archaeological sites, assemblages, and interpretations (Bugarin 2005) — a situation exemplified for prehistoric contexts around the globe.

In this paper, we will demonstrate that significant overlap exists between the material consequences of children's play and adult ritual behavior. While several authors have made brief mention of this situation (Bahn 2012, quoted above; de Maret 2016; Ucko and Rosenfeld 1967), not one has considered the issue in depth. Given the importance of identifying ritual and other aspects of symbolic behavior in the early archaeological record for understanding the development of human cognition and modern cultural diversity, it is critical to be mindful of this situation if we are to construct robust interpretations and representations of the past. Here we will focus on examples from the 
Eurasian Paleolithic but also include examples from other prehistoric contexts from around the globe to demonstrate the impact of moving archaeological objects and patterns from the ritual realm to the sphere of children for our understanding of deep-time communities.

\section{Archaeology of Ritual}

Early sentiment within archaeology held that material evidence considered indicative of ritual behavior required too much inference to be accurate (Hawkes 1954); however, during the past several decades, archaeologists have increasingly studied "ritual" to elucidate many facets of past social activity, especially those pertaining to power relations and identity, along with cognition and social memory (Swenson 2015). Indeed, the recent recognition that ritual is pervasive in all aspects of life has likely facilitated growing interest in this field of study (see Boivin 2009; Hodder 1982; Insoll 2004, 2009, 2012). Importantly, play itself, as practiced by both adults and children, can be seen as having a social ritual component (Rogersdotter 2011).

Divergent understandings of ritual in archaeology within different theoretical paradigms - often borrowed from anthropology - have resulted in an apparent dissonance between individual studies. While a detailed overview of the relevant theoretical developments is beyond the scope of this paper (see Insoll 2012; Swenson 2015), archaeological studies of religion and ritual have tended to travel alongside studies of symbols and meaning (Boivin 2009; Geertz 1973). For ease of understanding, when referring to ritual in this paper we are referring to the "habitual manifestations of religious beliefs which may leave material remains in the archaeological record" (Pettitt 2012:330).

\section{Archaeology of Children and Their Play}

The study of past children continues to develop as a subfield of archaeology. Archaeological literature prior to Lillehammer's (1989) seminal paper included few references to children and their childhood and picked up the pace from the year 2000 (e.g., Baxter 2005a, 2005b; Bird and Bliege-Bird 2000; Bugarin 2005; de Maret 2016; Grimm 2000; Kamp 2001, 2015; Sofaer Derevenski 2000). Despite this increasing interest in children of the past, however, we remain far from a routine consideration of their impact on the archaeological record and have consequently erased a significant proportion of past populations.

Children play. This behavior is universal, despite the differing cultures and lifeways practiced around the globe, and is thus "part of the human condition" (Gosso et al. 2005:214). Ethnographic accounts record the activities of children in varying depth, from great detail where the anthropologist was focused on the children as their central interest (such as Mead 1942, 1943) to a single sentence mentioning their primary occupation(s). While previous researchers have utilized the eHRAF (Human Relations Area Files) World Cultures database to construct cross-cultural samples for analysis (i.e., Ember and Cunnar 2015), this study simply aimed to find as many descriptions of children and their play activities from as many different environmental and regional hunter-gatherer contexts as possible with the ethnographic literature available to us through our respective universities. While far from exhaustive, we were able to draw together data for numerous groups located in Africa, Southeast Asia, the Pacific, Australia, North America, and South America (see table 2).

Play behavior can be divided into eight types: (1) exercise play, (2) exercise play with objects, (3) object play, (4) construction play, (5) social contingency play, (6) rough-and-tumble play, (7) fantasy play, and (8) games with rules (Parker 1984), with children from different cultures making "variations on a theme" based on their cultural background (Bloch and Pellegrini 1989; Fry 2005). Indeed, studies of great apes found that their young engage in several of these same types of play (e.g., Gómez and Martin-Andrade 2005; Lewis 2005; Ramsey and McGrew 2005), suggesting that childhood play has deep evolutionary origins (Pellegrini and Smith 2005; Slaughter and Domobrowski 1989). Thus, we can be certain that prehistoric children did play and that material objects would have been regularly incorporated into their games. This last point is important to archaeology, as it means that "toys" or "playthings" were used in the deep past, were deposited into the archaeological record, and will be recovered.

Certainly, many of the objects and features created during play can be expected to survive in the archaeological recordsurely we cannot uphold the notion that of the thousands upon thousands of prehistoric children to walk the landscape, they never played with anything but archaeologically fragile or archaeologically invisible items. Ethnographically, children from hunter-gatherer societies have played with toys that were made from a great range of raw materials, both organic and inorganic, archaeologically robust and archaeologically fragile (see table 1). These playthings may be directly given to a child by an adult as a plaything, they may be adult material culture items abandoned by adults and retrieved by children from refuse areas or elsewhere, they may be adult items abandoned by adults directly into children's hands, they may be objects made or altered by children themselves, or they may be unaltered natural items such as sticks, stones, or shells (Baxter 2005b; Bonnichsen 1973; Crawford 2009, 2011). Indeed, "toys are given significance and meaning by the children who play with them" (Crawford 2009:57), and thus, obviously, these factors make identifying potential playthings in archaeological contexts challenging, though not impossible.

Observations resulting from our review of the ethnographic literature mentioning hunter-gatherer children and their play, which are particularly important for the identification of archaeological children's activities, include (1) the raw materials from which a child's toy will be constructed depends on the natural resources available to the child/adult for producing playthings; (2) we can expect miniature hunting/fishing weaponry along with other miniature tools that are commonly utilized by the adults of the community; (3) we can expect figurines/dolls to be present; and (4) children will collect and frequently cache 
Table 1. Material playthings of children specifically mentioned in the hunter-gatherer ethnographies included in table 2 (sources)

\begin{tabular}{|c|c|}
\hline Type & Plaything \\
\hline Miniature weapons & $\begin{array}{l}\text { Arrow; bark missiles; blowpipe; boomerang; bow; crossbow; fighting sticks; fishing line; fish spear; mud missiles; } \\
\text { peashooter; shield; spear; spear-thrower; throwing-sticks }\end{array}$ \\
\hline Miniature tools & $\begin{array}{l}\text { Basket; canoe; comb; coolamon; digging stick; dilly bag; dogsled; food pounder; grindstone; hearth; hut; infant } \\
\text { carrier; kayak; oil lamp; raft; ramada; smoking pipe; snowhouse; stone ax; wickiup; windbreak }\end{array}$ \\
\hline Dolls & $\begin{array}{l}\text { Antler dolls/figurines; cattail dolls/figures; clay dolls/figures; cloth dolls; corn dolls; doll clothing; grass dolls/figures; } \\
\text { gum figures; mud dolls/figures; mud breasts; pottery dolls/figures; shell dolls; stick dolls; stone dolls; wax figures; } \\
\text { wooden (carved) dolls/figures }\end{array}$ \\
\hline Musical instruments & $\begin{array}{l}\text { Bone whistle; bull-roarer; buzz/whirling toy; cracking whip; grass whistle; hummer; flute; leaf whistle; panpipes; } \\
\text { seed rattles; seed whistles; shell rattles }\end{array}$ \\
\hline Ornamentation & Cloth; feathers; pigment; plant fiber plait-work; seed beads/pendants; shell beads/pendants; teeth beads/pendants \\
\hline Collectibles & Live animals (cassowary chicks, dogs, frogs, lizards, mockingbirds, roadrunners) \\
\hline Other game materials & $\begin{array}{l}\text { Balls (being made of grass, hair, moss, possum skin, sealskin); bark targets; bones (knuckles; ring-and-pin game); } \\
\text { cuttlefish; discs; drawing sticks; grass hoops; human bone; knuckle bones; leaves; marbles (seed/shell/stone/ } \\
\text { wood); playing sticks; shells; skipping rope; spinning tops; stick-dice; stones; string }\end{array}$ \\
\hline
\end{tabular}

unusual natural or anthropogenic objects. Table 1 summarizes the tools and weapons that have been specifically mentioned in ethnographies of hunter-gatherer peoples, while table 2 provides information for the specific groups for which this information is currently available.

With these observations in mind, we now reevaluate the most common artifacts and contexts that are routinely interpreted as residues of ritual activity in the Paleolithic Eurasian and other global prehistoric contexts: portable and parietal art, the collection of unusual objects, and arrangement and activity areas.

\section{Differentiating Children's Play from Adult Ritual in the Prehistoric Archaeological Record}

\section{Portable and Parietal Art}

The interpretation of Upper Paleolithic art in terms of magicoreligious motivations lies in the late nineteenth and into the early twentieth century recognition that prehistoric art could have more than a merely decorative function - that being a social function. It was this new paradigm that resulted in religious meaning being given first to Paleolithic portable art and then to parietal art (Palacio-Pérez 2010). This approach has continued into recent years (e.g., Conard 2003; Lewis-Williams 2002), though others have recognized that the thousands of portable art objects recovered from Upper Paleolithic Eurasia "have no readily apparent symbolic or ritual role" (Bahn 2012:348).

However, the creation of figurines for children or by children is ubiquitous in the ethnographic literature. Clay or mud is frequently mentioned in ethnographies from various contexts around the globe as a popular medium selected by children when making figurines themselves (e.g., Africa [Child 1969; Marlowe 2010:66; Sharman 1979]; North America [Elsasser 1978a; Kelly and Fowler 1986; Witherspoon 1983]; South America [Gosso et al. 2005; Leacock 1976]; Australia [Haagen 1994]). Furthermore, Kamp et al. (1999) have been able to give some temporal depth to these recent observations by using a combination of fingerprint measurements found on clay animal figurines and vessels recovered from Sinagua contexts in northern Arizona to demonstrate that at least some of these items were constructed by children.

Ethnographically, created figures include images of humans, animals, forms of transportation, and other common items from their surrounding environment (see an example in fig. $1 A$ ), and while many figures look like the creature or item they are moulded after, others bear little resemblance to their origins. A good example of this latter case is found in the clay dolls made by girls in northeast Arnhem Land. In 1935, Donald Thomson photographed a group of girls playing at being mothers in the Milingimbi area, where (as shown in fig. $2 A$ ) the girls were imitating their mothers by moulding clay breasts and a clay doll, collecting bark for the "baby" to lie on, and then copying the kneeling posture taken by women when breastfeeding an infant. One set of clay doll and moulded breasts is shown in figure $2 B$ (collected by Thomson at that time), and it is striking that the "baby's" only feature is a finger-poked depression representing the mouth. Given the lack of features, it seems doubtful that this item would be interpreted in relation to children if it were recovered archaeologically - and without corresponding ethnographical evidence. It is very conceivable that it would instead be linked to ritual behaviors, as are quite similar ca. 8,000-year-old Levantine artifacts known as "incised pebbles" (Gopher and Orrelle 1996; Stekelis 1972; Wreschner 1976).

Fired clay-pottery-dolls were constructed by adults for children in ethnographic studies (e.g., seen in Tipai-Ipai, CA; Luomala 1978), and Talalay (1993:48-49) has interpreted three Neolithic figurines found in Franchthi Cave, Greece, as children's dolls owing to their discovery among domestic activity areas. Dolls and animal figures are also made of hard animal materials such as bone, antler, and ivory in regions where such materials are abundant. Indeed, here fathers are reported as carving dolls (that are fully fitted out with tiny clothing) for their daughters (fig. 3A, 3B; Burch 1984), as well as a range of animals that were also used in games (Hughes 1984a, 1984b). Such time- or 
effort-intensive creations from ethnographic times are important for challenging previous interpretations of Upper Paleolithic antler and ivory figurines, which have been argued to be portable art pieces made for adult ritual use owing to the effort, time, or skill that went into their creation (e.g., Arias 2009; LeroiGourhan 1968), not to mention their appeal to our modern aesthetic.

Stone is also reported as being used in "fashioning dolls for children" (Powell 1990:433), as are parts of plants such as the wellknown cattail (Typha sp.) figures of North America (Ritzenthaler 1978). Which brings us to the famous split-twig figures of the Archaic period of southwest North America (fig. 4). Originally suggested to have been used in sympathetic hunting magic (e.g., Emslie 1987; Reilly 1966; Schroedl 1989; Schwartz, Lange, and deSaussure 1958), others have argued that these figures made in willow or other twigs were more likely to be children's toys (e.g., Jett 1987; Schroedl 1977), a suggestion supported by an apparent find of three examples (probably images of two deer and a duck) interred within the burial of a child in Utah (Jett 1991). This ca. 2,300-year-old burial was the first specific cultural/ functional context for split-twig figurines, previously reported examples being found scattered through habitation deposits but not in association with any particular feature. Those found in the Grand Canyon area were described as being "speared, and carefully placed in caches" and that "thus, the inferred functional interpretation, that the figurines were magico-religious objects used in a hunting ritual, seems to hold fairly well" (Schroedl 1977:263). However, it might be argued that the "ritual spearing" of the figurines could equally be the result of children playing at deer hunting and their discovery location attributed to children's caching habits (see below). Furthermore, at the Walnut Canyon site, "the ceiling of the overhang is very low, and most of the occupational evidence was found near the mouth. The figurines, however, were scattered throughout the less accessible portions of the shelter" (Euler and Olsen 1965:369), which one might suggest were more physically reachable to children and might provide a place in which they would play.

Along these lines are miniatures - small imitations or models of material culture - with their significance linked to the meaning of the original object (Foxhall 2015). These objects give children the opportunity to mimic and practice adult social roles and physical tasks in the context of their peer groups (Sutton-Smith 1986, 1994). A Queensland (Australian) example of such an item is described by Roth (1902:13), who reports that "the parents generally make miniature dilly-bags for their children to carry these dolls in," while numerous ethnographers report the occurrence of miniature weaponry (bows and arrows, spears, boomerangs) in hunter-gatherer and semipastoralist/semihorticulturalist cultures around the globe. Frequently these miniatures are made by the boy's father or other male relative, though in many cultures the boys were "encouraged to make and feather their own arrows" from the start (Goddard 1978:231). Indeed, in some cultures such miniature tools appear to have been an important part of passing on necessary life skills, with children "given toy versions of the tools they would later use as adults, played at adult tasks" (Seaburg and Miller 1990:562). To point out how easily a child's miniature tool might be mistaken for a ritual object, we provide the following example. At Kalanyoni Shelter, Zimbabwe, Walker (1995:172) reported that "the most interesting organic artefact is a small bone point (fig. 75:2) that recalls the miniature, magic, arrowhead of some Bushman groups (Bleek 1928; Dornan 1925) or quill barb on some arrows" (Goodwin 1945).

Beads and pendants are commonly classified by prehistoric archaeologists as portable art items and are central to debates surrounding human cognitive and behavioral development (e.g., Deacon 2001; d'Errico 2003; d'Errico et al. 2003, 2005; Kuhn and Stiner 2007; Mellars 2005; Wadley 2001). While we do not disagree with the reasoning behind their role in evolutionary investigations, we would like to point out that not only are children frequently the wearers of such bodily decorations but the very young are often the members of the community to wear the most decorations in day-to-day circumstances owing to beliefs that they need extra protection from harmful spirits or other entities (e.g., Guise 1899:207; Loeb 1928:431; Peterson 1978:39; Vanoverbergh 1937). For example, Xhosa babies were seen to wear shells, seeds, and animal-bone charms. Young children wore bracelets, armlets, and anklets, and children of all ages wore pieces of bark, root, bone, or animal claws (Child 1969). In southeastern Australia, Howitt (1904:525) observed that "small sets [of men's ornaments] are sometimes made to please little boys." And yet rarely do researchers consider the appearance of beads and pendants in the prehistoric record in terms of children at the site.

A second use of strung pieces of shell or beads, which not only would display the same use wear (and possibly residues) as beads worn against the body or clothing but is also likely to be as temporally and spatially widespread, is as babies' rattles. Ethnographically, the stringing of perforated marine, freshwater, or terrestrial snail shells for use as babies' rattles has been observed in numerous contexts globally, despite babies generally being ignored in early androcentric ethnographic accounts (a point made by several researchers, including Haagen 1994). For example, Roth (1902:519) noted that "rattles, for children, met wit on the Pennefather River [Cape York, Queensland], are made by stringing together particular shells and tying the ends," with similar such rattles observed in the Kimberley as well as the Maningrida area of the Northern Territory (Haagen 1994). Buzz or whirling toys are another example of perforated and strung pieces that are frequently linked to the amusement of children in hunter-gatherer ethnography (e.g., Arima 1984; Honigmann 1981; Silver 1978a, 1978b; Suttles and Lane 1990) but that may be interpreted as remains of a personal ornament or a ritual item if recovered archaeologically.

Another sound toy commonly given to young children are whistles or simple flutes, yet such items, when recovered from prehistoric contexts, are usually assigned a ritual association, moving them away from the more mundane existence of everyday communities (e.g., Caldwell 2009; Ibáñez et al. 2015). Along these lines, "bull-roarers" regularly feature in ethnographies as 


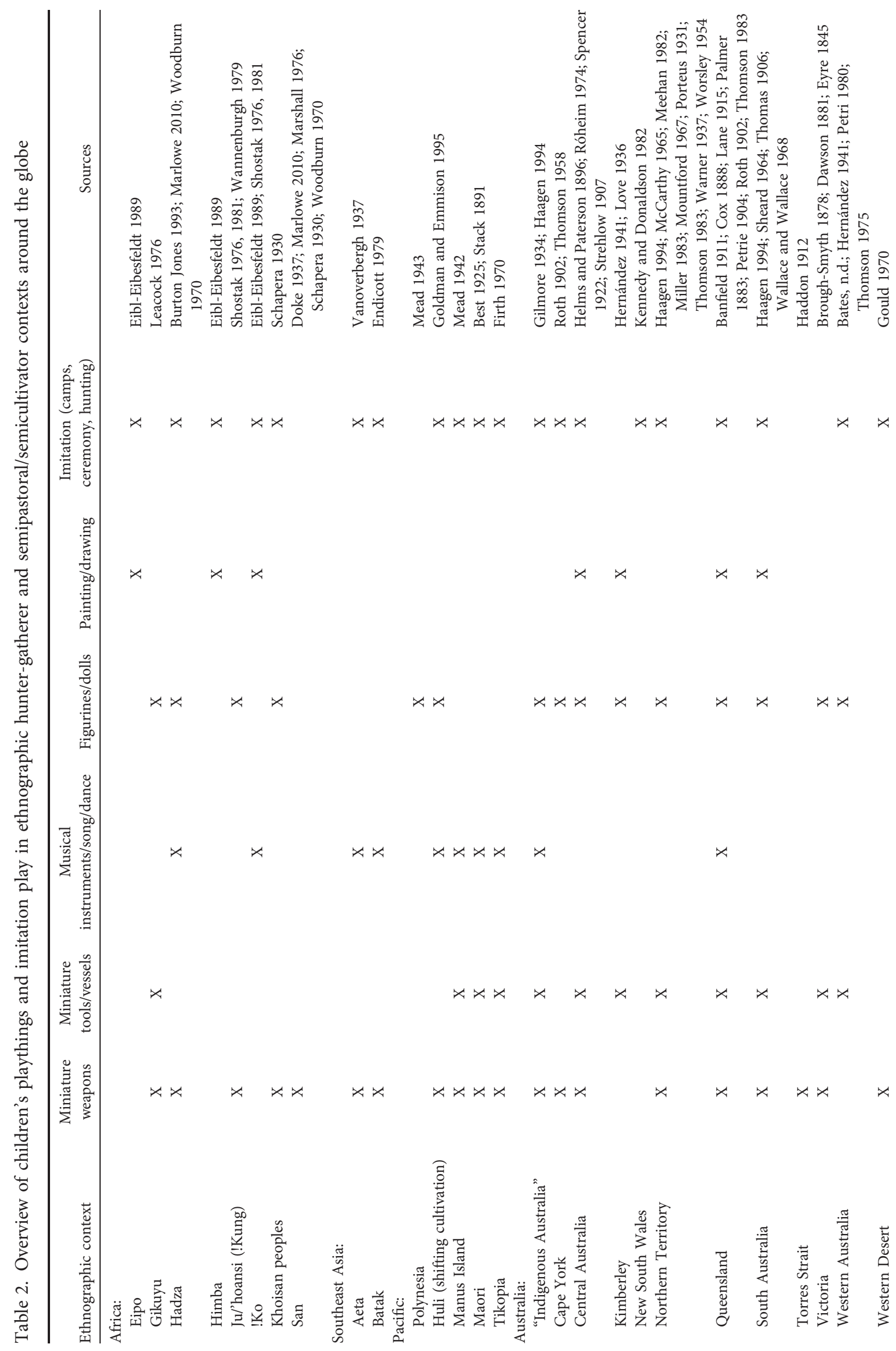

620

This content downloaded from 130.056.097.188 on February 14, 2019 18:39:34 PM 


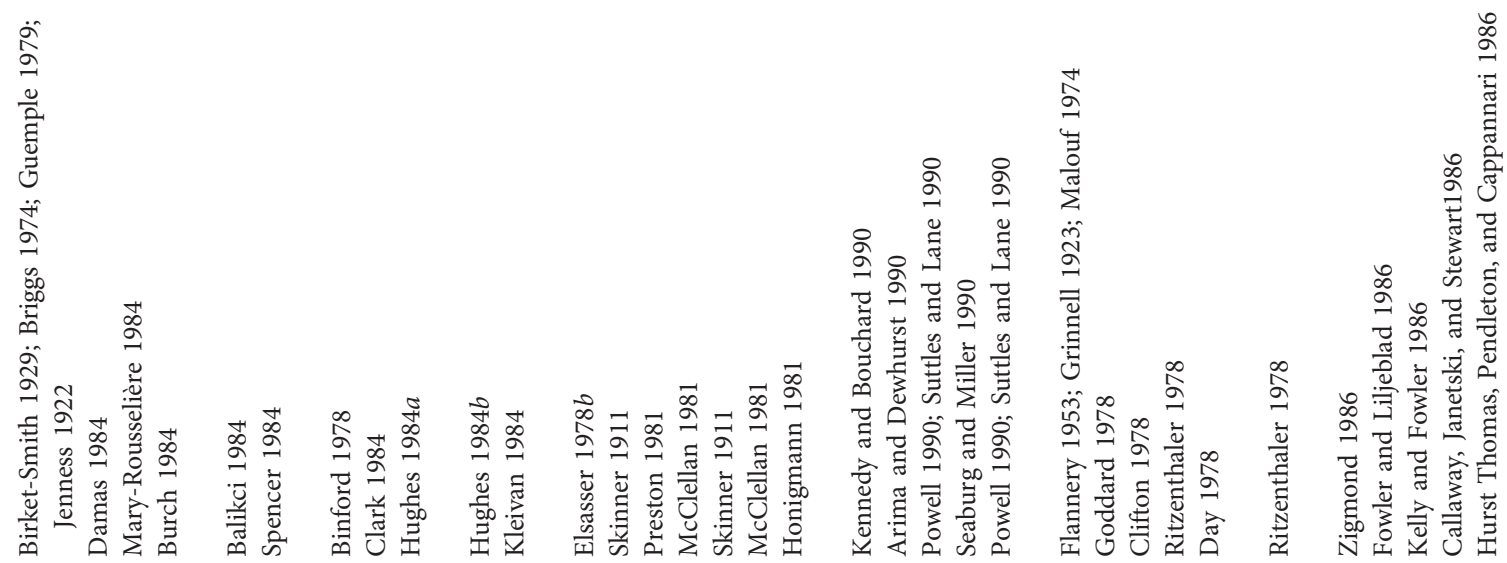

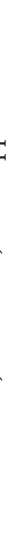




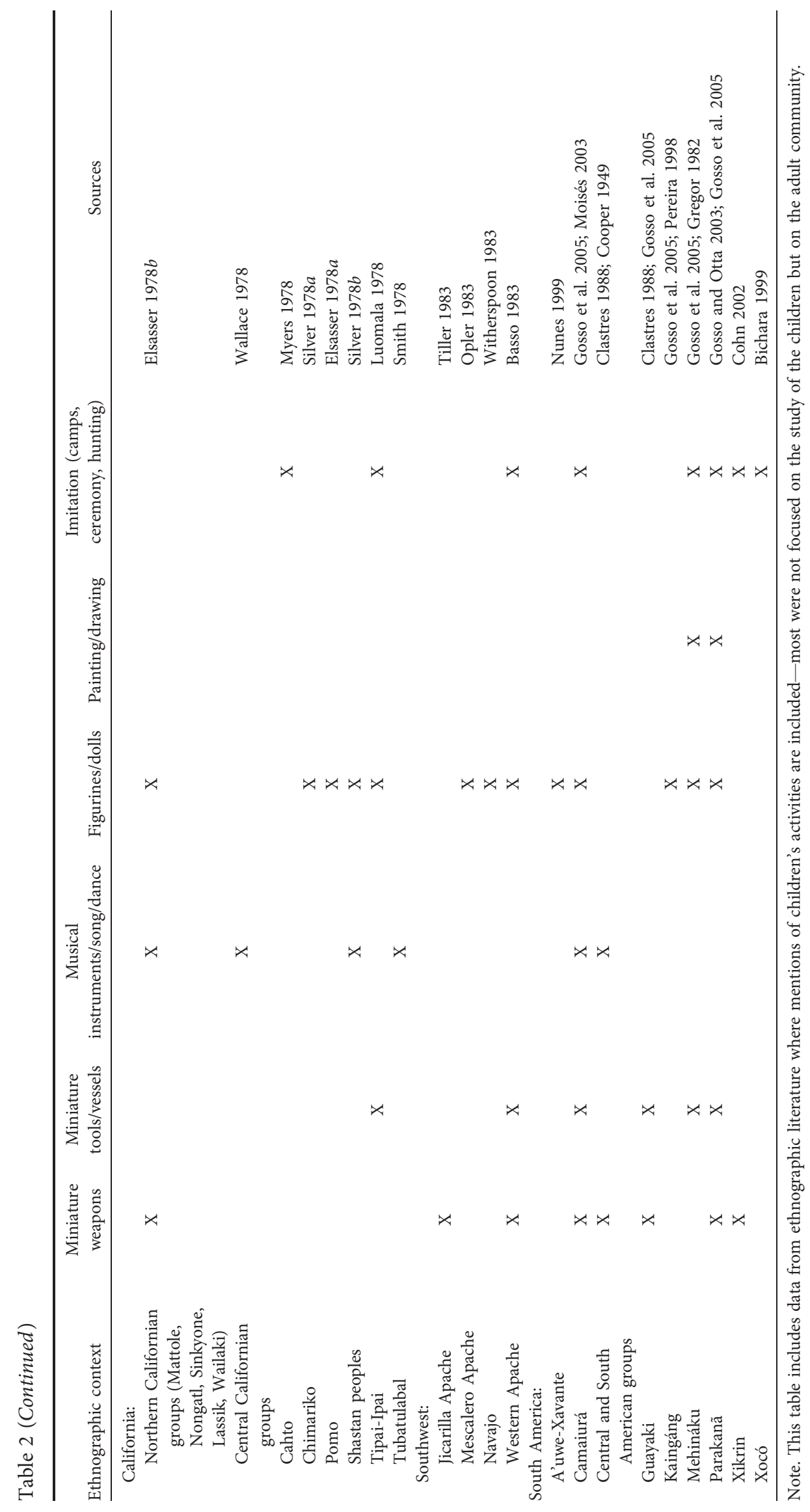

This content downloaded from 130.056.097.188 on February 14, 2019 18:39:34 PM All use subject to University of Chicago Press Terms and Conditions (http://www.journals.uchicago.edu/t-and-c). 

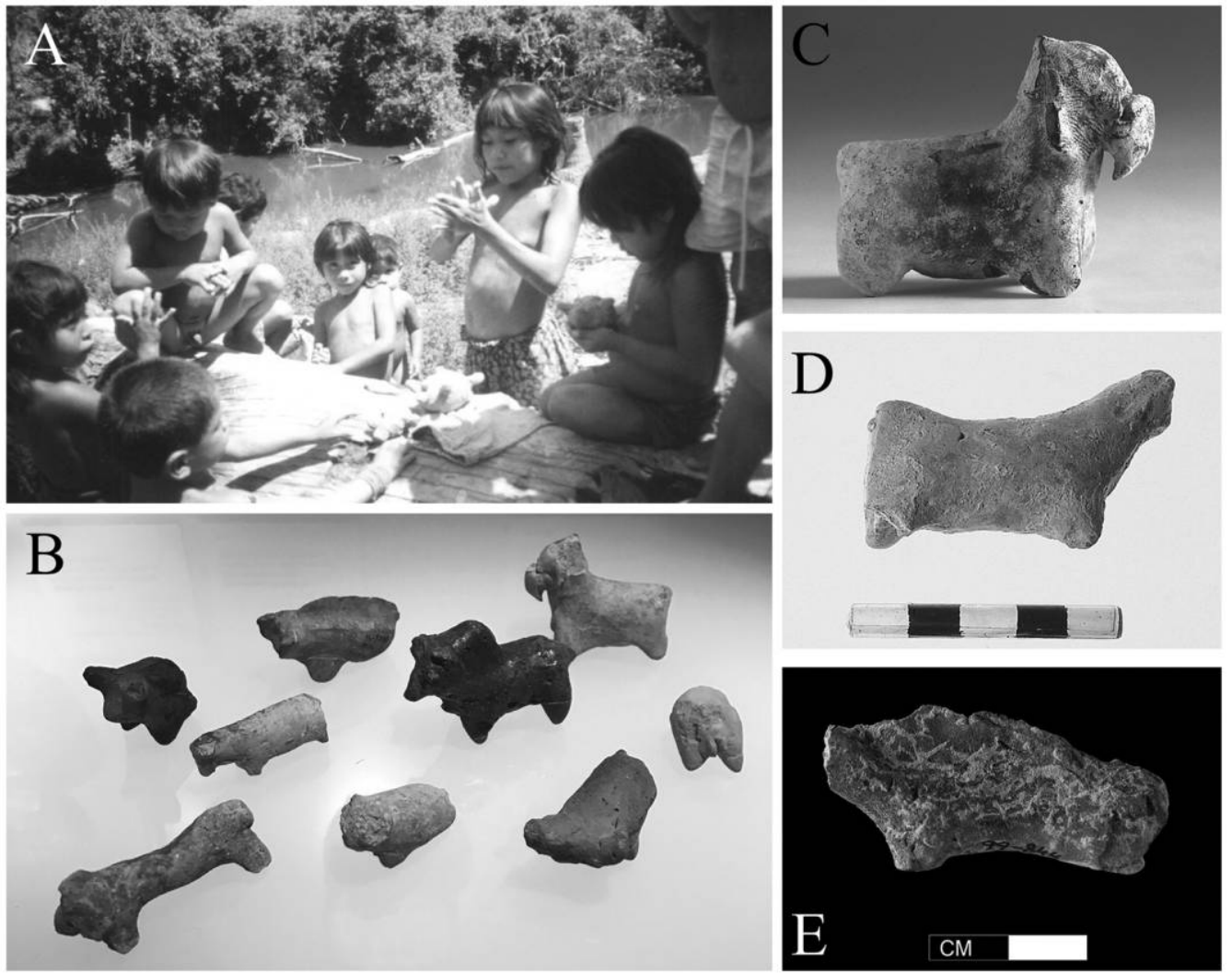

Figure 1. Children and clay/mud figurines. A, Parakanã children making mud figurines in Brazil. Photograph by Y. Gosso. $B-E$, Clay animal figurines from the Yarmukian culture (ca. 8,000 BP), Israel. These artifacts have been interpreted in several ways, including as children's toys and as adult ritual votives (Freikman and Garfinkel 2009). Photographs by M. Langley, included with permission of the Israel Museum (B), and Y. Garfinkel, Shaar Hagolan Expedition, Hebrew University of Jerusalem $(C-E)$. A color version of this figure is available online.

objects of children's amusement (e.g., Australia [Roth 1902]; North America [Honigmann 1981; Smith 1978; Spencer 1984; Suttles and Lane 1990]). A perforation is drilled into one extremity of a flattened, spindle-shaped piece of wood (or other material) so that a string can be attached to the pendant, which is then whirled around to create the roaring sound. These instruments are just as frequently cited as restricted ritual objects in communities (e.g., by the Washoe, Great Basin [d'Azevedo 1986]; parts of Greater Australia [Van Baal 1963]). Despite these recent observations, however, in the archaeological literature surrounding musical instruments recovered from Paleolithic/prehistoric contexts, these items are invariably linked to ritual and are frequently argued to be one of the most powerful indicators of ritual behavior in the deep past (e.g., Morley 2009; Neal 2013).

Indeed, some ethnographically recorded toys incorporate raw materials that we might otherwise interpret as having had a symbolic function. For example, we might consider feathers, something that has led to a reevaluation of Neanderthal personal ornamentation in recent years (e.g., Finlayson et al. 2012; Peresani et al. 2011) but that are often a component of children's playthings. One such example is the Kalahari !Kung zeni, a feather attached to a weight (a pebble or nut) with a leather thong about
$15 \mathrm{~cm}$ long (Draper 1976; Wannenburgh 1979). The player hurls the zeni using a stick. The weight falls with the feather fluttering behind acting as a parachute. The objective of the game is to reach the zeni and strike it again before it hits the ground. Interestingly, the /Gwi believe that were it not for the zeni, humankind would still be living in darkness, so this common children's plaything also has a place in their symbolic realm.

Furthermore, ethnographers have described games played by both children and adults that include small objects. For example, Best (1925) describes a Maori game in which a small, smooth, waterworn stone is passed from one player to the next in a circle while reciting a charm or song - "as the repetition of this ceased one of the players, who did not form one of the circle, attempted to guess as to who had the stone" (1925:117). Such a natural object would obviously accrue significant wear from handling if curated over time for play. On the other hand, if a stone or other object was simply selected from their surroundings at the beginning of each game, such singular objects may simply arrive in the archaeological record in an unexpected area.

Like musical instruments, colorants have also been strongly linked to symbolic or ritual behavior in the deep past (e.g., Deacon 2001; d'Errico 2003; d'Errico et al. 2003; Mellars 1996, 

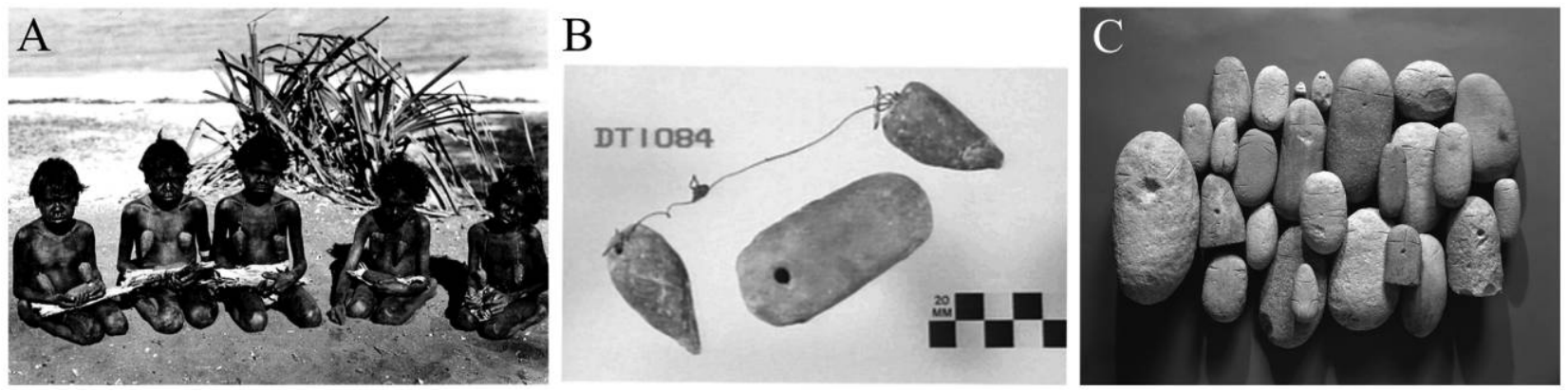

Figure 2. Simple dolls. A, Girls playing at being mothers at Milingimbi, northeast Arnhem Land, Australia, in 1935. Photograph by D. Thomson, image TPH1262. B, Clay dolls and breasts collected by Donald Thomson in 1935. Photograph by Museum Victoria, image DT1084. C, Yarmukian "incised pebbles" on display in the Israel Museum. Photograph by M. Langley, included with permission of the Israel Museum. A color version of this figure is available online.

2005). However, as with musical instruments, body painting is also reported as a common children's activity in recent huntergatherer communities, including among Parakanã (Brazil) girls who are seen painting their peers or their own bodies (Gosso and Otta 2003), while Anbarra (Northern Territory, Australia) chil- dren were witnessed in a similar behavior (Hamilton 1981). We always assume that utilized ochre was employed by adults for ritualized purposes; why is the input of children never considered? Certainly, children are physically capable of collecting and utilizing mineral pigments and producing utilized ochre nodules
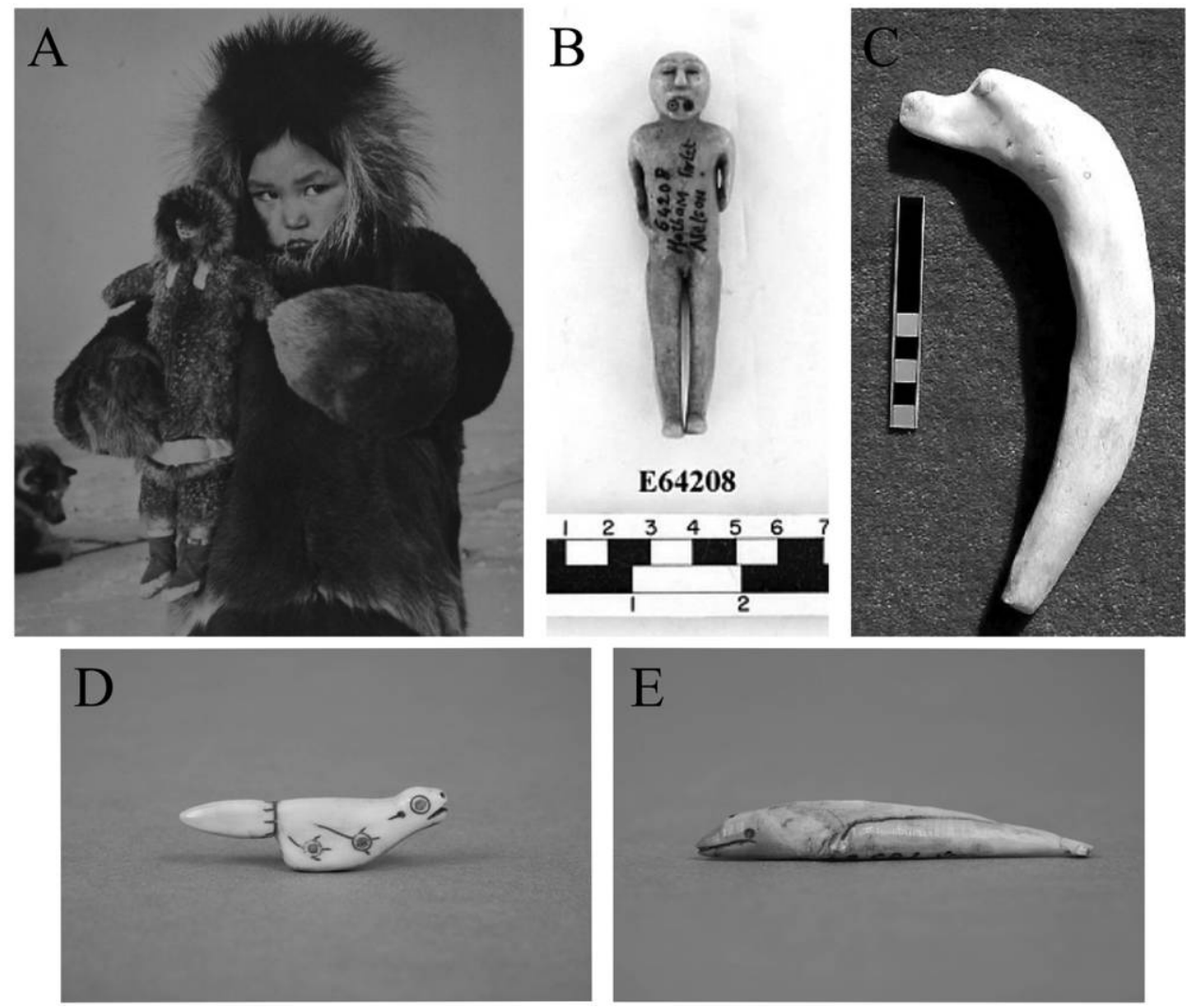

Figure 3. Hard animal material figurines. A, An Inuit girl showing her homemade doll near Coppermine, Northwest Territories, 1949. Photograph by R. Harrington, courtesy of the Stephen Bulger Gallery. B, Ivory figure made by a child's father collected by E. W. Nelson at Hotham Inlet, Alaska, 1877-1881 (Department of Anthropology, Smithsonian Institute, 64208). C, Toy rainbow snake made on dugong (Dugong dugon) rib bone collected by K. Akerman in Maningrida, Northern Territory, Australia. Photograph by K. Akerman. D, E, Ivory toys collected from Cape Vancouver, Alaska, pre-1880 (Department of Anthropology, Smithsonian Institution, E43585-0 $[D], \mathrm{E} 43591-0[E])$. A color version of this figure is available online. 

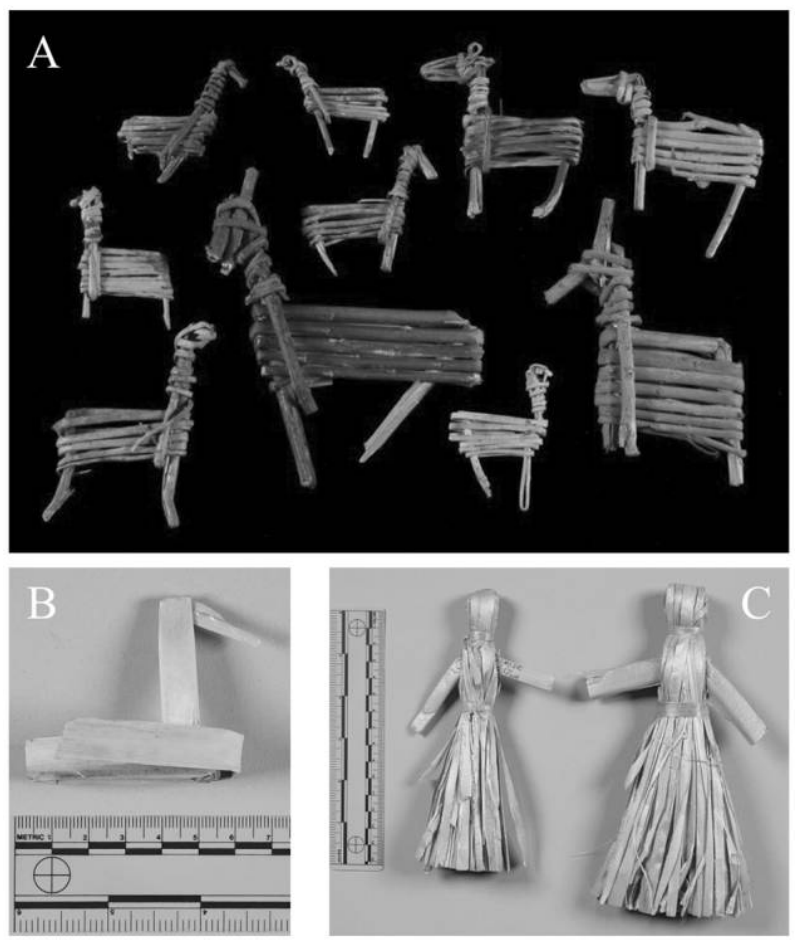

Figure 4. Plant-based figurines. A, Split-twig figurines from the Archaic period of the southwest of North America. Photograph courtesy of the Southwest Virtual Museum and Grand Canyon National Park. $B, C$, Ethnographic dolls made on cattail leaves (Typha sp.) by Chippewa woman Frances Densmore (Department of Anthropology, Smithsonian Institution, E317213-0 [B], E317214-0 $[C])$. A color version of this figure is available online.

very similar to those recovered from deep-time archaeological contexts (see fig. $5 E, 5 F$ ).

Unlike the previously mentioned material culture, the application of colorants in the creation of Paleolithic parietal art already has links to children in the literature. Handprints belonging to children have been found at sites such as Gargas and Bedeilhac, where the prints belong to infants, while at Fontanet handprints of a 5-year-old have been located (Clottes 1997). Hand stencils belonging to children are also noted at sites such as Altamira (Freeman et al. 1987), Cosquer (Clottes, Courtin, and Vanrell 2005), and Gargas, where a baby's hand was apparently held by an adult while colorant was blown over the both of them (Bahn and Vertut 1988). Similarly, some of the finger flutings made in the soft clay walls of caves are suggested to have been made by the very young. Sharpe and Van Gelder (2006) argue that flutings found in Rouffignac were made by children aged between 2 and 5 years, with the aid of adults who hoisted them aloft to create their marks in otherwise unreachable places. Van Gelder (2015) has also identified marks made by children in the decorated caves of El Castillo, Las Chimeneas, and Gargas. These tiny marks have led to suggestions that initiation rites or other significant social occasions were held in these locations (Arias 2009; Bégouën 1926; Breuil 1952; Hadingham 1979;
Leroi-Gourhan 1967; Owens and Hayden 1997; Pfeiffer 1982), though others - interestingly — have suggested that they simply represent youthful exploration and play (Ucko and Rosenfeld 1967).

\section{Collection of the Unusual}

The ubiquity of useful collecting behaviors in humans - such as those related to tool manufacturing supplies and foodhas been thought to be the result of evolutionary selection for individuals with this behavioral predisposition (Anderson, Damasio, and Damasio 2005). However, the collection of unusual objects or "curiosities" - unmodified objects made of exotic or rare raw materials but for which it is difficult to propose a functional use - are frequently mentioned in investigations into the origins of symbolic or ritual behavior. In these debates, the collection and transport of small natural items with arresting qualities has been used to suggest that Neanderthals (in particular) had an aesthetic sense (e.g., Chase and Dibble 1987; Otte 1996). Items frequently reported as such indicators of early symbolic behaviors include calcite and quartz crystals (Bednarik 1995; Demars 1992; Goren-Inbar, Lewy, and Kislev 1991; Moncel 2003; Moncel and L'Homme 2007; Pei 1931; San-Juan 1990; Watts, Chazan, and Wilkins 2016), pyrite (Leroi-Gourhan 1964), recent and fossil shark teeth (Clot 1987), and fossils (Bednarik 2014; Demars 1992; Leroi-Gourhan 1964; L'Homme and Freneix 1993; San-Juan 1990; Soressi 2002).

While the use of such manuports for identifying symbolic behavior in Lower and Middle Paleolithic contexts is debated (e.g., d'Errico, Gaillard, and Misra 1989; Soressi and d'Errico 2007), the recovery of such items in more recent (modern human) contexts is routinely assigned to shamanistic or otherwise ritualistic actions (e.g., Dickau, Redwood, and Cooke 2013). While these interpretations are usually not made without strong ethnographic analogy, authors regularly state ritual as a compelling interpretation for the presence of manuports in their sites, such as the quartz crystals and "rare sparkling mineral" manuports present in Holocene sites in California (e.g., Koerper, Desautels, and Couch 2002). Another example is the presence of triton shells (Charonia sp.) in Mediterranean sites from the Neolithic onward, with a regular cult or ritual interpretation suggested for their presence in sites (e.g., Aström and Reesee 1990; Peltenburg 1989; Skeates 1991).

The collection of curiosities, however, is a widespread behavior beginning in childhood (Lekies and Beery 2013) and is linked to the fact that gathering objects allows an individual to have control over an object in a way that they are not allowed in other sectors of their life (Danet and Katriel 1994). Easily movable parts of the environment (such as stones, flowers, berries, leaves, sticks, etc.) have been said to foster creativity and experimentation and to be "hypnotizing and irresistible to children under six years old, almost calling to be touched, stacked, carried, or collected" (Sutton 2011:409). There are also indications that collecting in childhood is undertaken as part of building knowledge of their environment and the diversity it holds. For 

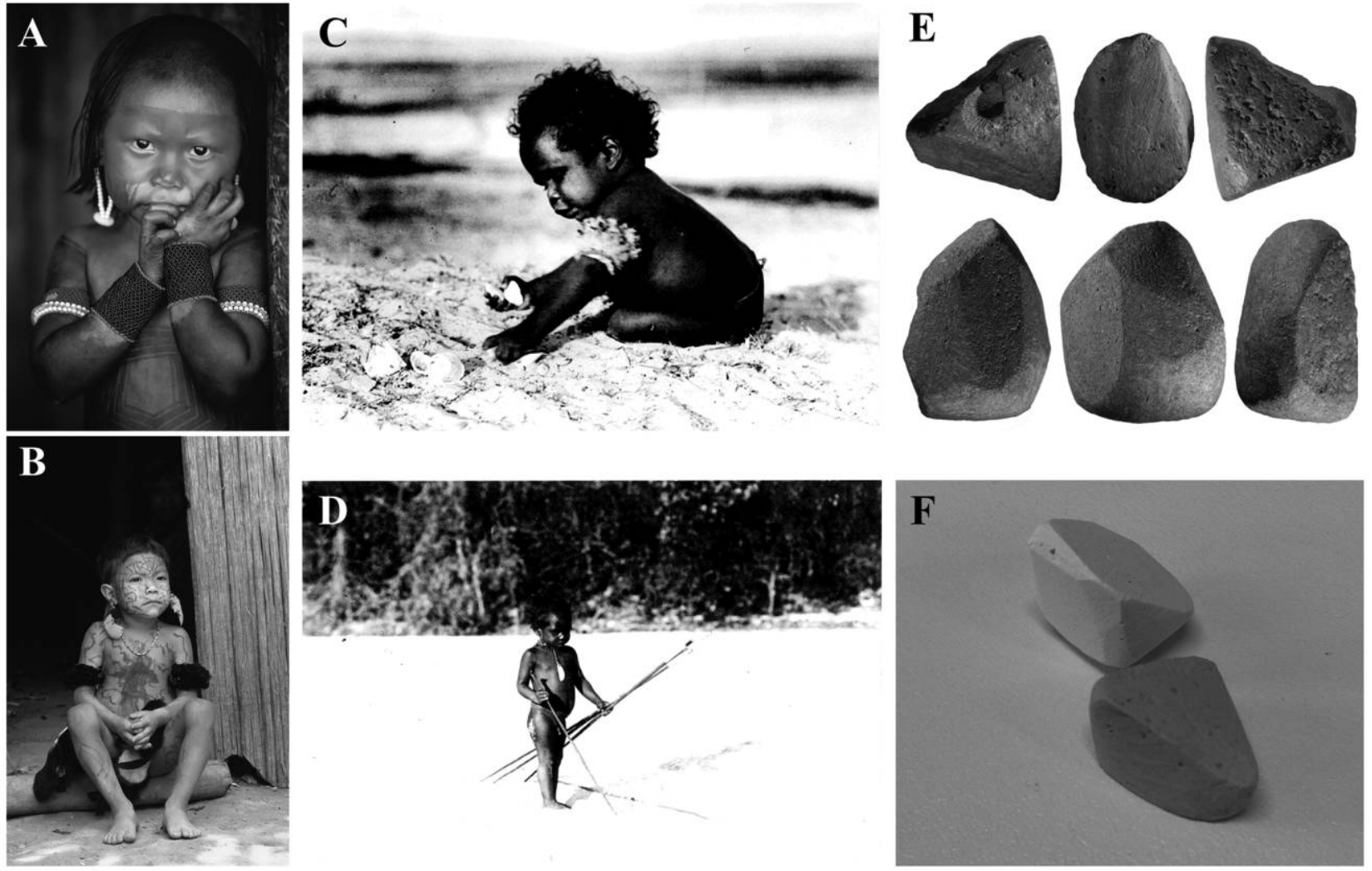

Figure 5. Decorated children. A, Kayapo girl, Kapoto Village, Para, Brazil. B, Yanomano boy, Parima Tapirapeco National Park, Venezuela. Photographs for $A$ and $B$ by A. Wolfe (http://www.artwolfe.com). C, Warramirri child playing with shells in the Melville Bay area, northeast Arnhem Land, 1935. Photograph by D. Thomson, image TPH1267. D, Cowargie with practice spear and spear-thrower, Ompela Tribe, Stewart River, Cape York Peninsula, Australia. Photograph by D. Thomson, image TPH2948. E, Utilized ochre nodules from Châtelperronian layers at Grotte du Renne (courtesy of F. d'Errico). F, Utilized chalk nodules discarded as too small for continued use by one of the authors' (M. C. Langley) 22-month-old daughter. A color version of this figure is available online.

example, Chipeniuk (1995) found that adolescents who had collected broadly had a significantly better understanding of biodiversity than narrow collectors.

Unfortunately, mentions of the collecting habits of huntergatherer-fisher children in the ethnographic literature are limited, though not necessarily because they didn't collect (that seems unsupportable) but because ethnographers have largely not been interested in the activities of children. Thus, we also turn briefly to the collecting habits of Western children. Rock and shell collections are particularly common (Lekies and Beery 2013; Whitley 1929), with an early study of American schoolchildren finding that "the chief points of attraction [to stones collected] were color, shape, smoothness, brilliancy and beauty. Under shape the attributes mentioned most were smooth, flat, round. Under color, white, pink bright, brilliant, red, dark blue, yellow, sparkling, stained; those with holes in them were also attractive" (Acher 1910:124). Importantly, these are the same attributes commonly shared by the collected "exotics" found in prehistoric contexts.

Also commonly collected for or by children are small live animals, which are then kept as pets (table 1). For example, Roth
(1902:9) reports for Australian contexts that "the Bloomfield [Aboriginal community] are very fond of playing with young rats, bandicoots, wallabies, etc., as pets" while at Cape Bedford "young birds, rats, frogs, etc., tied with a string are given to the children to play with," with similar descriptions for peoples in the Cairns area and lower Tully River. Similarly, in North America "mockingbirds and roadrunners were caged for pets" by TipaiIpai in California (Luomala 1978:601), while in South America parrots and small monkeys appear to be popular (fig. 6). In contexts where dogs are used in hunting or transport, puppies are regularly integrated into child's play: "a very young boy would have a small sledge, to which he harnessed puppies" (Mary-Rousselière 1984:436; see also a photographed example in fig. $6 F$ ).

These things collected and played with by children were then curated and stored, with American children stating that they kept their collections in "attics, basements, garages, trunks, boxes, and locations where others could not find them such as under boards or in dog houses" (Lekies and Beery 2013:68). Stored caches, when found in colonial archaeological contexts, however, are often interpreted as apotropaia-charms, which are typically 

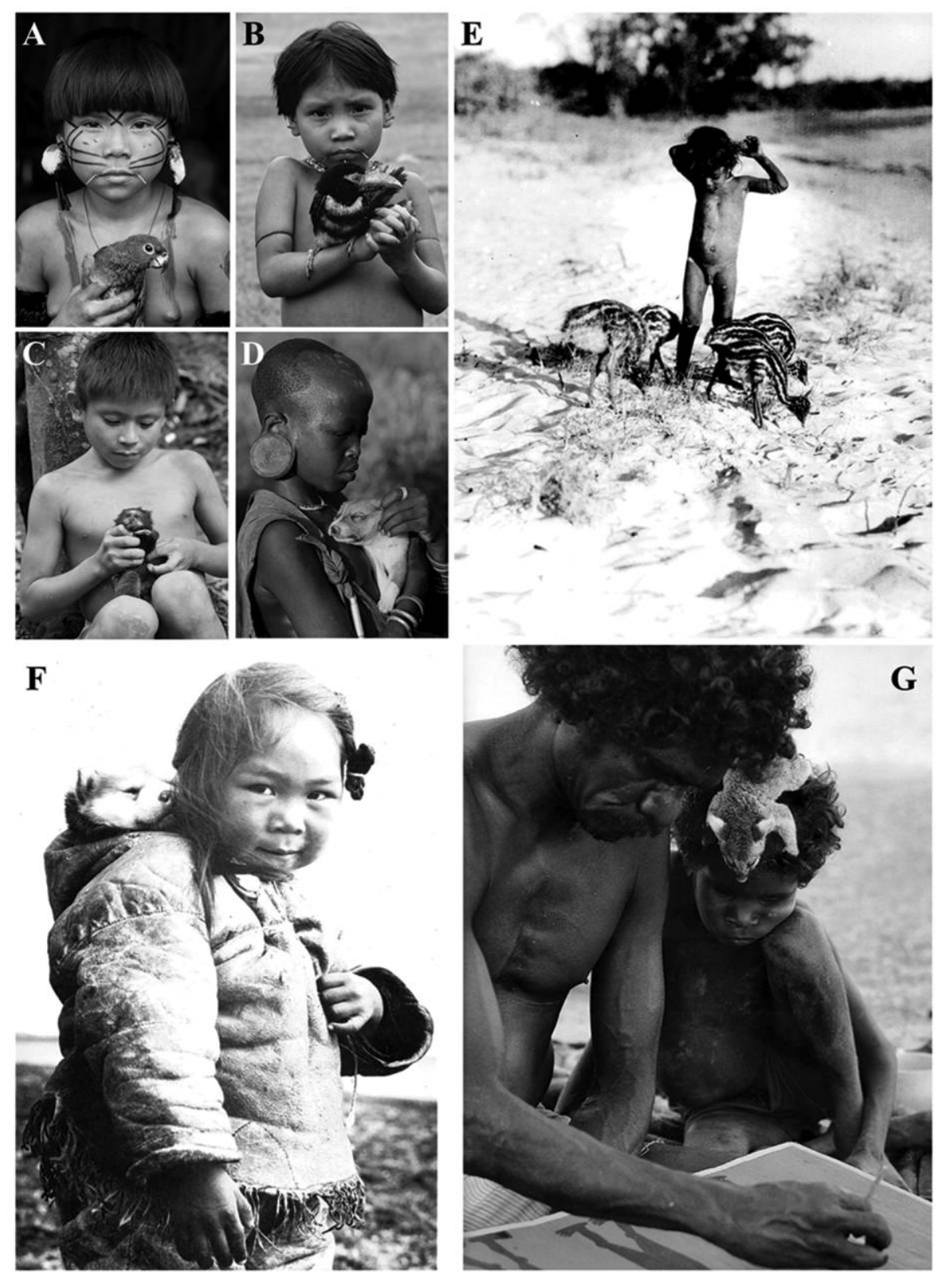

Figure 6. Ethnographic images of hunter-gatherer children with "collected" creatures. A, A Yanomamo girl holding her pet parrot, Amazon rainforest. $B$, Yanomamo girl holds aracari, Parima Tapirapeco National Park, Venezuela. C, A Machiguenga boy holds a black-mantled tamarin, Manú National Park, Peru. $D$, A Mursi girl holds a puppy, Omo River, Ethiopia. Photographs for $A-D$ by A. Wolfe (http://www.artwolf.com). E, Son of Wonggo, Garmali family, in Caledon Bay, northeast Arnhem Land, with emu chicks. Photograph by D. Thomson, image TPH1543. F, Eskimo girl with puppy, Coppermine, Northwest Territories, 1949. Photograph by R. Harrington, courtesy of the Stephen Bulgar Gallery. G, Graham Malibirr with pet possum watching his father George Milpurrurr paint. Photograph by P. Tweedie, courtesy of the Australian Institute of Aboriginal and Torres Strait Islander Studies. A color version of this figure is available online.

everyday objects - used in folk magic. Burke, Arthure, and de Leiuen (2016) discussed the archaeology of folk magic in colonial Australia, which included the recovery of objects such as shoes and perforated coins from voids under floorboards and near fireplaces. An earlier study by Evans (2010) examined deliberately concealed objects in old houses and buildings in
Australia and found that $41 \%$ of shoes belonged to children, which we argue emphasizes the need to consider children's caching activities in these discussions. As Burke, Arthure, and de Leiuen (2016) point out, establishing the meaning of these collections will be problematic, and convincing archaeological examples of children's caches are rare, with one of the only ex- 
amples identified by Wardle and Wardle (2007). In Macedonia, a collection of figurines, miniature vessels, animal bones, and other items was found in a pit at the site of Assiros Tomba, and by ruling out other interpretations for the find (funerary, accidental, symbolic, functional) they provide a robust case for a late Greek prehistoric child's cache of playthings. A recent example from America is provided by Dozier (2016): the cache included pieces of ceramics, glassware, machinery metal, and clothingodd things found as discarded by adults.
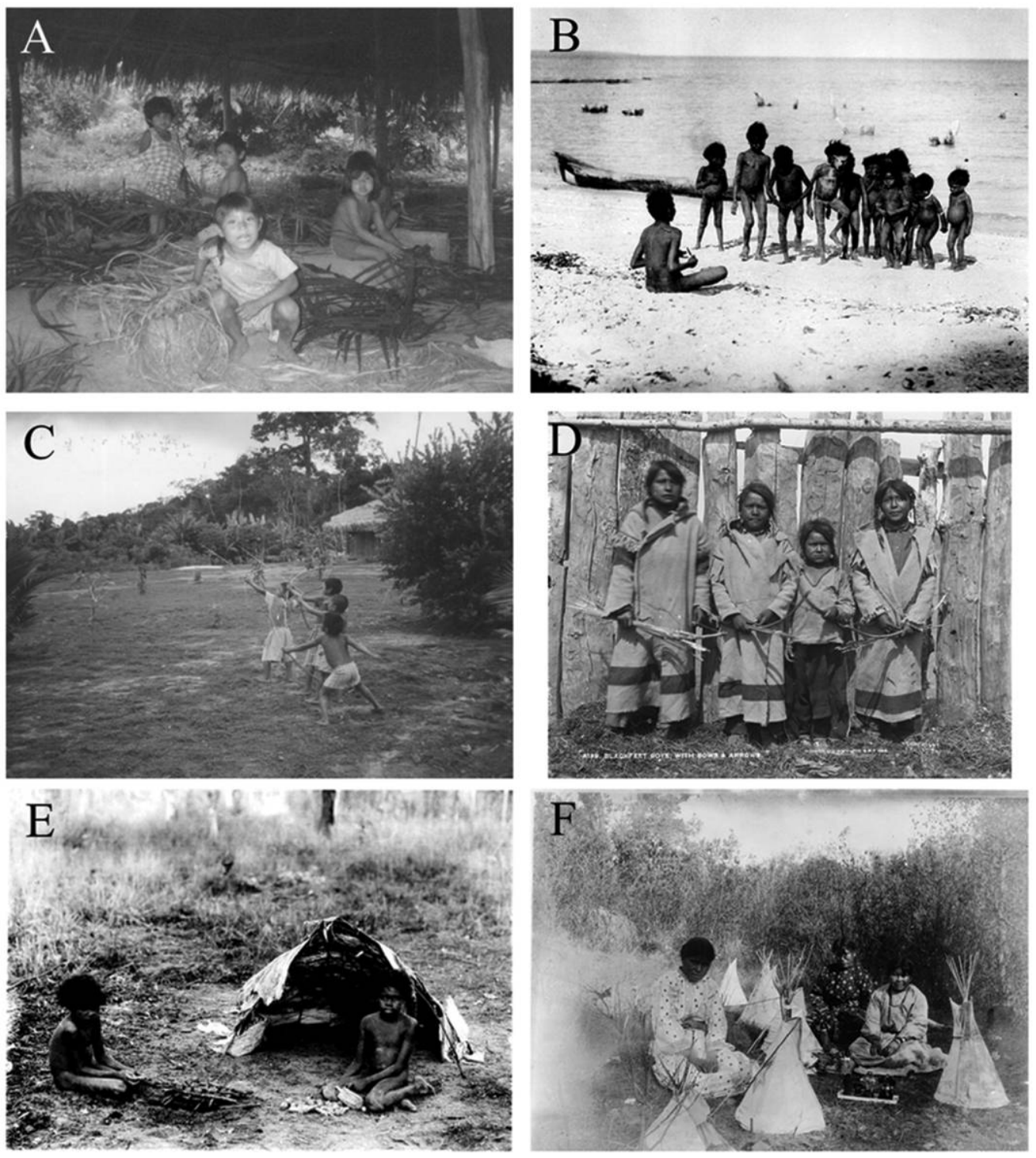

Figure 7. Ethnographic images of children imitating adult behaviors. A, Parakanã (Brazil) girls playing at weaving baskets. Photograph by Y. Gosso. B, Children in northeast Arnhem Land (Australia) playing at ceremony. Photograph by D. Thomson, image TPH1277. C, Parakanã (Brazil) boys practicing with miniature bows and arrows. Photograph by Y. Gosso. D, Blackfoot boys (North America) with miniature bows and arrows (Provincial Archives of Alberta). Photograph by E. Brown, image B34. E, Cape York (Australia) children playing at "house" having made a miniature hut and fire. Photograph by D. Thomson, image TPH2921. F, Cheyenne (North America) girls playing with miniature tipi dollhouses and dolls. Photograph by J. Tuell, Library of Congress Prints and Photographs Division, Washington, DC, image 12921. A color version of this figure is available online. 
functional implements. For example, Gould (1970:4) mentioned of Australian Western Desert peoples that "young children sometimes take their father's spear-thrower or spear, or one belonging to someone else and play with it, and, on occasion, damage it."

Unwanted items could also be handed directly to children by adults - such an artifact then entered a "toy stage" prior to final abandonment (Crawford 2009). One such example is mentioned by Woodburn (1970:19) for the Hadza of Tanzania, who reports that "eventually an arrow becomes too short for use and it is then handed over to a child or thrown away." Identifying whether a specific archaeological object passed through such a child-associated stage may be impossible to determine, a point previously made by Crawford (2009).

When thinking along these lines, it then becomes interesting to reconsider not only what archaeologists term "opportunistic recycling of lithics" but also the many findings of flint tools and animal teeth in niches of Paleolithic decorated caves. While some examples do appear to provide sustainable evidence for ritual behavior, such as at Les Trois Frères where such items are located in niches below a prominent depiction of a lioness bearing evidence for repeatedly having been pounded on the head and shoulder (Bégouën and Clottes 1980), many others may not have any ritual association at all-instead simply being the result of children sticking items in holes. A possible example is found in Toriano Cave, Italy, where pellets of clay appear to have been thrown forcefully against the back wall of the innermost chamber, $400 \mathrm{~m}$ from the entrance, at least 12,000 years ago (Blanc 1957). While usually interpreted as the consequence of ritual, Bahn (2012) conversely suggests that it could equally be an example of play.

\section{Patterns in the Record: Arrangements and Activity Areas}

Other patterns found in the archaeological record that are regularly interpreted as residues of adult ritual behavior may instead be the product of child's play. Imitative games - where a child or group of children play at adult activity: "house," "grown-ups," "marriage," "mothers," "hunting," "ceremony," "shaman," "war," and so on-are a prominent feature of children's social play (Fry 2005), and it is not surprising, then, that they are frequently described in ethnographies from around the globe. Some have described this fantasy behavior as "playing at culture" (Gosso et al. 2005:244), with these games including the use of not only miniature tools (discussed above) but miniature constructions such as huts, fences, or fireplaces (fig. $7 E$; see table 2). One such example is shown in figure $7 E$, where children in Cape York (northern Australia) are playing at house: "they make play houses of the same kind as those in which they live and play at keeping house" (Thomson 1958:91), and Ngamba children (New South Wales) get "stiff necks from playing all day in miniature miamias that they built for themselves" (Kennedy and Donaldson 1982:8). Along other lines, miniature versions of ceremonies are arranged either by the children themselves (as seen in fig. $7 B$ ) or sometimes with the help of adults as part of teaching them important activities they will undertake on reaching adulthood: among the Bella Colla (northwest coast of North America), "a chief would arrange for a 'play potlatch' . . characterized by feasting, singing, dancing, and the distribution of goods (in the form of miniature canoes, baskets, bows and arrows, etc.); all these activities were modelled on those of the real potlatch" (Kennedy and Bouchard 1990:333).

Given the ubiquity of hunter-gatherer children creating "play activity areas," we should expect to find evidence for such play in the archaeological record also. Preservation of such ephemeral features is obviously a major factor in identification, though several sites with potential have survived. Perhaps one such example can be found in the recently reported structures found in Bruniquel Cave, southwest France, and dated to 176,500 years BP (fig. 8; Jaubert et al. 2016). Constructed from whole and broken stalagmites, a small $2.2 \times 2.1-\mathrm{m}$ circular structure (structure $\mathrm{B})$ is found next to a much larger $(6.7 \mathrm{~m} \times 4.5 \mathrm{~m})$ annular structure (structure A). At the entrance of the smaller structure $\mathrm{B}$ is evidence for heating and burnt bone remains, while evidence for heating is found in several locations within structure A. Another example of imitative behavior might be a small hearth consisting of only a layer of charcoal above burnt sediment and containing no archaeological material (hearth 2) that was identified only a few meters away from a large multiphased hearth (hearth 1) at the Gravettian site of Krems-Watchberg (Austria). Analyses of the charcoal recovered from both hearths found that it was possible to connect the two- - both having been used synchronously (Cichocki, Knibbe, and Tillich 2014; Händel et al. 2014). The location of such small anthropogenic features close to larger ones is consistent with ethnographic observation of children locating themselves (or according to adult supervision) "a few yards from the main camp" (Turnbull 1961).

For a final example, we might consider the well-known case of a cave bear skull (Ursus spelaeus) found in Chauvet, France. The cave bear skull was placed on a rock, initiating discussions of a "cave bear cult," which have long been dismissed. As Bahn (2012) highlights, this discovery could be evidence for play, and there is little way of distinguishing the two. Interestingly, many footprints recovered from Upper Paleolithic caves belong to youngsters and adolescents, which could be a result of play and natural inquisitiveness (Bahn 2012; Ucko and Rosenfeld 1967).

Finally, how we see other patterns in the archaeological record could be affected when we integrate children into our interpretations - the most obvious example being "aggregation sites." In identifying sites where usually regionally dispersed groups came together to participate in various economic and social activities, Paleolithic archaeologists look for four main attributes: (1) site size - the need to accommodate a large group of people engaged in multiple activities; (2) site density- evidence for lots of people/activity; (3) exotic raw materials - indicating movement of people from various and distant lands; and (4) intensity of symbolic material culture (beads, pendants, portable art pieces, utilized ochre) - thought to indicate increased signaling and ritual behaviors (Bahn 1982). Given ev- 

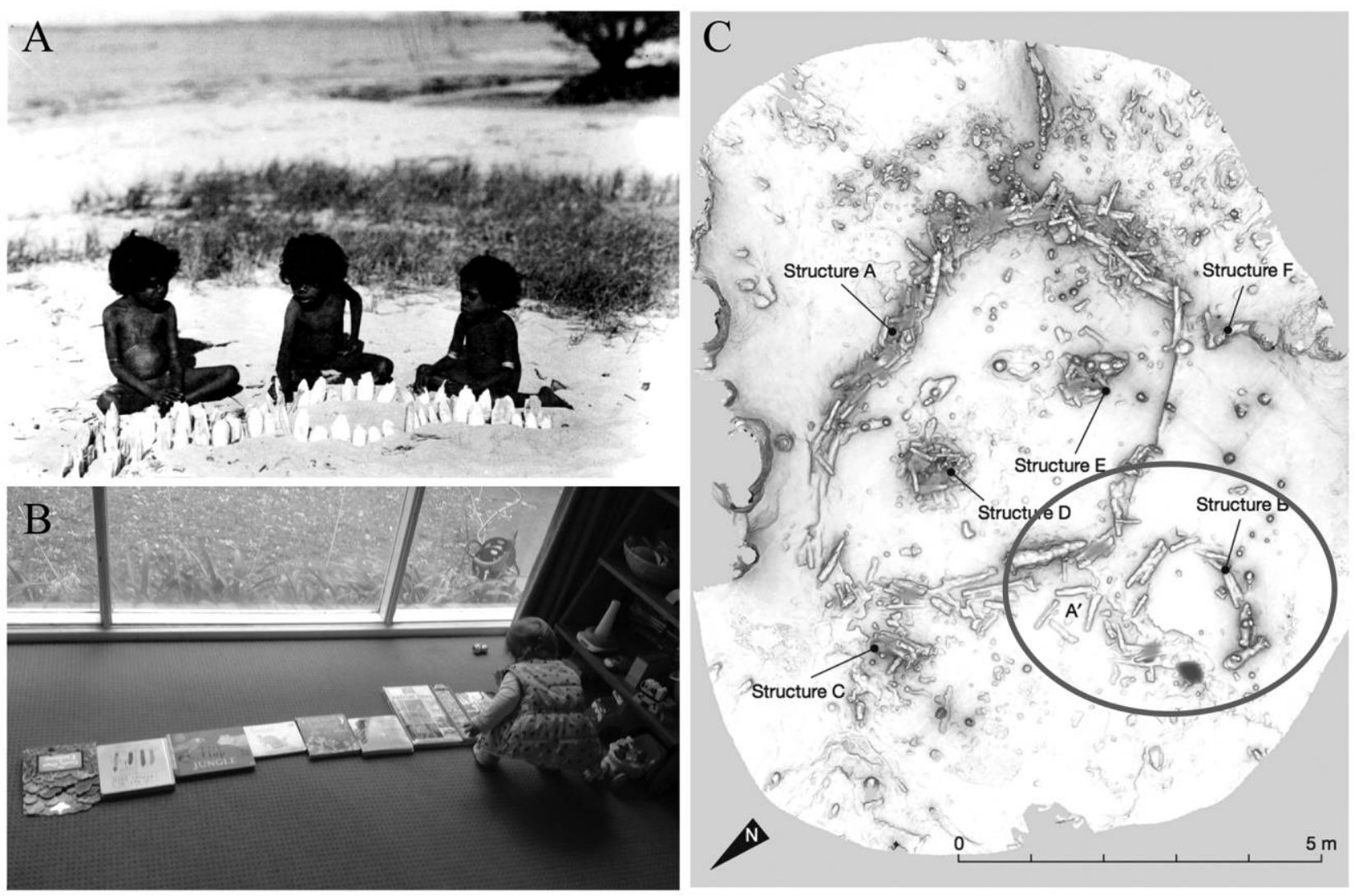

Figure 8. Arrangements and children. Children of all backgrounds love to arrange items into patterns. A, Arrawiya children arranging cuttlefish at Wonggo's camp at Trial Bay, northeast Arnhem Land, July 1935. Photograph by D. Thomson, image TPH1250. $B$, One of the authors' daughters (M. C. Langley) at 18 months arranging books into a line. Photograph by M. Langley. C, 176,500year-old stalagmite structures in Bruniquel, France. The circle outlines a small feature that may be the product of a child imitating adult behavior (the larger structure; after Jaubert et al. 2016:112, fig. 1, courtesy of J. Jaubert and Nature Publishing Group). A color version of this figure is available online.

erything described above in this paper, it could be suggested that increased "symbolic" content at such sites may not necessarily equate to increased signaling and ritual events among the adults but simply more children on site.

\section{Discussion and Conclusion}

\section{As Johnson (2010) articulates so well:}

One of the most frequent clichés heard is that we cannot "see" the individual in the archaeological record. However, pots are made by people: in a very large part, the archaeological record contains very direct evidence of individual actions and human interactions - the digging of a rubbish pit, the construction of house formations, the manufacture of objects, the deposition of grave goods ... over and over again ... we have seen different theoretical attitudes leading us away from agency. (224)

We would argue that this same attitude has resulted in researchers forgetting to take into account the presence and ac- tivities of the prehistoric child, undoubtedly ending up with archaeological discoveries being labeled as "ritual" or "symbolic" instead of, more simply - "children present."

Previously, the inclusion of children in the interpretation of Paleolithic sites has been restricted to a handful of areas: the creation of parietal art (e.g., Bahn and Vertut 1988; Bégouën et al. 2009; Breuil 1952; Clottes 1997; Sharpe and Van Gelder 2006; Ucko and Rosenfeld 1967), burials (for an overview of Paleolithic burials, see Zilhão 2005), and as apprentices in tool or image making (e.g., Bodu, Karlin, and Ploux 1990; Fritz 1999a, 1999b; Fritz, Tosello, and Conkey 2015; Grimm 2000; Karlin and Pigeot 1989; Olive 1988; Pigeot 1990; Rivero 2016; Shea 2006). However, we hope to have demonstrated not only that children can and should have produced a much wider range of archaeological residues but also the importance of differentiating between these residues and those resulting from adult ritual behaviors. Importantly, this point is not made simply to further cast children as a distorting effect on the archaeological record that must be drawn out but instead to prompt conscious 
attempts to identify whether an artifact or feature was the result of one or the other. Such analysis will result in archaeologists not only being able to more clearly study adult ritual actions in the deep past but also fueling the development of prehistoric childhood studies.

Such a tremendous overlap between potential material residues of ritual and the activities of children obviously represents a major interpretive issue in archaeology and is one that has not previously been considered in depth. We need to acknowledge and recognize children's agency in the archaeological record if we are to build the most comprehensive reconstructions of the prehistoric past possible, and we are heartened by the fact that a handful of researchers have already recognized that "most scholars automatically favour the cult or ritual interpretation" over the presence of children (Wardle and Wardle 2007:29). Certainly, it is essential that archaeologists not only consider whether possible instances of ritual behavior might instead reflect the actions of children in newly uncovered deposits but also revise interpretations of previous excavations with children in mind. Indeed, the inclusion of children in archaeological interpretations is essential if we hope to create a more complete and dynamic picture of past societies, their development, evolution, and demise.

\section{Acknowledgments}

Many individuals and organizations provided digital copies and permissions for including the images shown in this paper, without which the work would be lacking. We therefore thank Kim Akerman, Francesco d'Errico, Yosef Garfinkel, Yumi Gosso, Jaques Jaubert, Art Wolfe, the Thomson family, the Australian Institute of Aboriginal and Torres Strait Islander Studies, Grand Canyon National Park, the Israel Museum, Library of Congress Prints and Photographs Division (Washington, DC), Museum of Northern Arizona, Museum Victoria, Nature Publishing Group, Provincial Archives of Alberta, the Smithsonian Institution, and the Southwest Virtual Museum. We also thank Colin Pardoe for his encouragement and insightful discussions surrounding this topic, as well as the constructive comments of our anonymous reviewers. This research was supported by the ARC DECRA grant DE170101076 to M. C. Langley.

\section{Comments}

\section{Daniella E. Bar-Yosef Mayer}

Steinhardt Museum of Natural History, Tel Aviv University, Tel Aviv 69978, Israel (baryosef@post.tau.ac.il). 21 X 17

That children lived in (what are now archaeological) sites is unquestionable. Without them, there would have been no "us."
But how can children, or the products of their activities, be recognized in the archaeological record? This is a rather elusive challenge that has been visited by a number of researchers (e.g., Coşkunsu 2015).

Langley and Litster discuss children's behavior and in particular the material culture that supports their play while providing many ethnographic examples from around the world, and they note that "significant overlap exists between the material consequences of children's play and adult ritual behavior." They wonder to what extent children and their activities are visible and recognizable in the archaeological record.

It is implied that small or miniature artifacts, often referred to in the archaeological record as "figurines," are associated with ritual activity and are regarded as small-scale items that are made by adults and for adults and thus served in various ceremonial activities, whereas the authors show multiple examples from the ethnographic literature that suggest that they are merely toys. A case of small children-sized fingerprints on clay animal figurines supports this notion.

Martin and Meskell (2012), studying animal "figurines" from Çatalhöyük, did not study fingerprints but did consider the option that these artifacts might have been children's toys. They contend that for the figurines to have been toys there should have been a choice of more familiar animals (such as sheep or dogs) rather than wild beasts, more stylized forms, and clusters of animals found together that were not found. Furthermore, none are ever found in children's graves at Çatalhöyük that are abundant at the site and contain numerous other types of grave goods; thus, they dismiss the interpretation of the figurines being toys. Freikman and Garfinkel (2009), on the other hand, propose that the burial of clusters of animal figurines indicates the burial of cultic objects and not toys. Thus, apart from artifacts being small and suitable for children's play, there should be additional criteria to differentiate between children's toys and adults' figurines.

Another topic that is in the subtext of this article but not discussed per se is to what extent these toys, or miniature items, are mediated to children by adults. In other words, whether adults are responsible for the use of these items by children although it has nothing to do with rituals. A case in point is 13 pendants made of Unio shells from a baby's burial at Çatalhöyük. The pendants have two perforations each; their shape is that of a rounded square, and they are especially thin (ca. $1 \mathrm{~mm}$ in thickness). A microscopic examination of the holes showed that the pendants were pristine with no wear, suggesting that they did not decorate this child or any other person and were probably produced to serve as grave goods (Bar-Yosef Mayer 2013:333, fig. 16.8). Although the pendants were found in a child's grave, they are the product of adult behavior, both the production and the insertion into the grave. In a similar way, toys in many cases would have been made and given by adults to children and therefore reflect decision-making and actions of adults. The cases presented by Langley and Litster of children's handprints in Paleolithic parietal art and possible marks 
reflecting initiation rights are perfect examples of the presence of children at sites, yet a behavior that is mediated by adults. Adults, then, could have been responsible for the toys, beads worn by children, ritual artifacts, and the stenciling of children's hands, making it even harder for the archaeologist to distinguish between them.

\section{Jane Eva Baxter}

Department of Anthropology, DePaul University, 2343 North Racine Avenue, Chicago, Illinois 60614, USA (jbaxter@depaul.edu). 29 XI 17

Albert Einstein is commonly credited with saying, "It's not that I'm so smart, it's just that I stay with problems longer." This quip humbly deflected a popular fascination with his genius but was also very insightful about the nature of intellectual inquiry that is often characterized as pioneering, groundbreaking, or innovative. Ritual and children are two archaeological "problems" that few chose to stay with for very long until relatively recently. Traditionally, each was used as a hasty and often spurious explanation for archaeological enigma that were considered too singular, unique, or ambiguous to be subject to a reliable or valid archaeological explanation. The authors of this work acknowledge the common archaeological inside joke where artifacts or features defying an easy functional explanation are offhandedly referred to as being "ritual items." Children, while not having the same casual in-joke quality, have been invoked in archaeological literature in much the same way for generations. Deploying ritual and children in this way relegated them to the realm of the unknowable or archaeologically inaccessible while simultaneously diminishing their perceived importance as topics deserving of scholarly attention. Archaeological interests and attitudes have changed significantly in recent decades and moved toward interpreting the past in ways that embrace the humanity of archaeological subjects while also taking a rigorous approach to archaeological evidence. An article that juxtaposes ritual and children as issues of significant interest, particularly in deep prehistory, is indicative of this disciplinary transformation and serves as an important contribution on this trajectory of disciplinary change.

Seeking children in the distant past using nonmortuary data is among the earliest types of childhood studies in archaeology (Shea 2006; Sofaer Derevenski 2000) and is an area of research that has gained a great deal of traction in recent years, with a notable diversification in theoretical and methodological approaches to identifying and interpreting children as part of past communities (see Cunnar and Höberg 2015). This article makes a significant contribution to this corpus of literature, and one particularly notable feature is the tone in which it was written. The authors do not take time to justify the value of children, nor do they dwell on the "cautionary tales" that have dissuaded others from studying children in the past. The result is a different kind of narrative that assumes the value of children, assumes the validity of the archaeological study of children, and assumes that children can be studied effectively if we approach the archaeological and ethnographic records appropriately. The authors delve into the ethnographic record in a way that justifies all of these assumptions. This kind of approach to studying childhood without the benefit of written texts or rich iconography and particularly to study children for their own sake and in their own right is a departure from much of the earliest work on the archaeology of childhood and is indicative of a growing confidence that archaeological methods alone can be used effectively to access children in the past.

This article also situates play and ritual as embodied practices that have meaningful behavioral and material correlates. While ritual may be deeply embedded in intangible culture and play entrenched in the imagination, these are not their exclusive domains, and seeking the material expressions of play and ritual in the archaeological record is rightly characterized as very possible and desirable. This article illuminates the artificial boundaries that linger in archaeology around symbolic meaning and embodied action and challenges archaeologists to think about the material and spatial dynamics of ritual, and play more specifically.

Given the interplay between the intangible and material in children's play, the authors make it clear that not all play will be equally visible archaeologically. Their systematic and tenacious review of the ethnographic record enabled the development of concrete expectations for archaeologically visible play. The authors chose to focus on the subset of children's play behavior that uses toys. This choice of subject and narrative style enabled them to take on the ambiguity of certain artifact types, such as figurines, which have been interpreted as toys and ritual items in different contexts, often with little certainty or resolution. Here the authors make a convincing case using the archaeological record that many figurines encountered archaeologically are likely the material expressions of children's play behavior in the past, and they offer ways for scholars to write children into prehistory with a greater sense of certainty. In this way, this work is part of a growing trend in archaeology where authors are embracing the universality of human play and identifying toys and play behaviors as expected and meaningful aspects of the archaeological record.

Simultaneously, other scholars are seeking ways to decouple the reliance on finding toys or child-specific material culture to write children into prehistory. These relational approaches also assume the presence of children in the past and explore landscapes and material culture not along an adult-child divide but rather as a meaningful constellation of places, spaces, and objects with which all members of human social groups were engaging in the quotidian and exceptional practices of their lives. This alternative approach is equally significant, as it assumes that children were present and important in the past but offers a way to decouple the worlds of children from the activities and objects designed exclusively for their use. In either case, these works are illustrating the value of "staying with the problem longer" and enriching our views of past communities as richly human, inclusive, and multigenerational. 


\section{Adam Brumm}

Environmental Futures Research Institute, Griffith University, Sir Samuel Griffith Building (N78), 170 Kessels Road, Nathan, Queensland 4111, Australia (a.brumm@griffith.edu.au).6 XI 17

\section{"I Think One of Your Children Has Just Walked In"}

Reading this paper called to mind the recent video of an American academic, Robert Kelly, being interviewed on BBC World News about Korean politics. Kelly, a political scientist, was conducting the TV interview live from his home when his two young children burst into the room. His 4-year-old daughter is the first to appear, swaggering into view like a rock star, followed soon by his 8-month-old son trundling along in a baby walker. Kelly struggles straight-faced through the questioning until his wife rushes in and drags the intruders out of the room, eldest toddler squealing indignantly. The YouTube video has been viewed tens of millions of times. Any parent can relate to Kelly's predicament: children are irrepressible, and their presence - and in particular the mess and bedlam they seem to effortlessly create-is impossible to ignore.

Not so for archaeologists, it would seem. In this paper, Michelle Langley and Mirani Litster offer a view of the archaeology of early humans that would have children invading the ancient world - "our" world - in the same way that Kelly's kids crashed his interview. Children were long ago shoved into the back room by archaeologists and told to be quiet, they argue. The influence kids may have had on shaping the Paleolithic record has been overlooked; in fact, artifacts we routinely interpret as hallmarks of the ritual actions and other behavior of adults may be things that were mostly used or interacted with by children, or even created by them. For instance, the authors toy with the idea that the famous carved animal figurines from Upper Paleolithic Europe could actually be examples of prehistoric children's playthings.

Let us look at this last point. The tragedy of Langley and Litster's argument is that it is very tough to prove. What sort of smoking gun evidence would be required to demonstrate that, say, the 40,000-year-old ivory statuettes from the Swabian region were kids' toys: the discovery of one of these artifacts in a child's grave? Even then, how could we tell that they were not objects from the grown-ups' world placed in the burial as part of a mortuary ritual? Langley and Litster's argument requires very high standards of proof. But equally difficult to verify or refute is the conventional story about the meaning of Aurignacian figurines - that they are portable art, expressions of hunting magic, religious symbols, shamans' accoutrements, and so on. The notion that Paleolithic figurines belong to the cryptic world of adult ritual life is a line of debate and speculation that has become firmly entrenched as a paradigm. But perhaps the received wisdom is a house of cards; interpreting them as playthings seems just as valid based on the same standards of nonproof.

Australian archaeologists have long been disdainful of the "it's ritual" adage, supposedly a postmodern European thing. So while I think that Langley and Litster's paper will go down well here, or at least not go under, I suspect that few Australian archaeologists and not a great many worldwide will enthusiastically embrace the replacement adage: "it's children." Indeed, there is a sense that if Aurignacian figurines or other venerated artifacts of prehistory were shown to be "just" playthings, then the archaeological enterprise as a whole would feel rather let down. Perhaps some archaeologists might feel a bit silly. After all, a lot of academic ink has been spilled expounding elaborate and high-level explanations of these objects and their ritualistic functions. If Langley and Litster are right, should the deposed artifacts of Paleolithic ritual be relegated to museum drawers filled with lithics and other dreary data of "domestic" life? Or should the discovery of the hidden world of Paleolithic children be something archaeologists should yearn to accomplish if we wish to understand - to truly understand - the lives of past people?

I am not sure how they propose to do it, but if they can do it, Langley and Litster's call to uncover the existence of children in the archaeological record could yield profound new insight into the evolution of humankind in its present form. Chimpanzees (our closest genetic kin) and other great apes engage in social play with their offspring. They teach and care for their progeny just as we do. Some female chimps even seem to play at being mum with sticks (Kahlenberg and Wrangham 2010). What about extinct humans? We can be reasonably sure that closely related species such as Neanderthals formed deep emotional bonds with their children and played games and roughhoused with them. They also did modern humanlike things such as adorning themselves with ochre and ornaments. But did parental play among Neanderthals extend to crafting toys that were more complex than unmodified stick "dolls"? Could this be what makes Homo sapiens unique, if we are unique, from an evolutionary standpoint-is it only us who create distinct classes of material culture that are special to the world of children's play?

Children may be set to barge into the respectable world of archaeology, ruining cherished theories about early human behavior just as thoroughly as two kids trashing a BBC interview. Would this be disappointing? I hope not; it is often said (or sung) that children are our future, but they are also our past, and it is clear that ancient kids still have a lot to teach us.

\section{Kathryn Kamp \\ Department of Anthropology, Grinnell College, Grinnell, Iowa 50112, USA (kamp@grinnell.edu). 25 X 17}

Both religious practices and the activities of children are, like adult activities, patterned. Nonetheless, an archaeological tradition that viewed children as mere disrupters of the archaeological record and religion as a viable explanation for anything unusual still lures archaeologists. Langley and Litster argue persuasively for new approaches that are more inclusive of children and that consider the nature of play activities in a more systematic way than has characteristically been true of archaeological interpretation. I argue that the next stage in developing these ap- 
proaches entails additional ethnoarchaeological research combined with use-wear studies.

Using a comprehensive review of the ethnographic literature on hunter-gatherer children, Langley and Litster make a good case for overlaps between objects used in ritual and those associated with children's play. Archaeological examples demonstrate that archaeologists frequently choose a ritual interpretation in the face of such ambiguities, although they provide notable exceptions. While Langley and Litster focus on hunting and gathering societies, their analysis is more broadly applicable. Recent discussions of past childhood emphasize the ubiquity of children in all societies and the likelihood that children were in fact a proportionally large fraction of the population in many of the societies studied by archaeologists. It is certain that children affected the material record. Given that children's play would have left material traces, it is almost certain that an adult-centered archaeology has failed to identify its traces.

As with the best and most provocative scholarship, Langley and Litster's research should spur additional questioning and inspire new investigations. These may take two different but not incompatible paths: (1) the reevaluation of some past archaeological interpretations to consider whether either children or play activities are viable alternatives to previous ritual interpretations and (2) studies of material culture that will assist us in differentiating the play activities of children from the ritual activities and play of adults. While Langley and Litster acknowledge that both adults and children engage in play, their study tends to set up a dichotomy between children's play and adult ritual activity. Play, quite obviously, should not automatically be associated with children. Details of artifact type, context, and use wear may all provide additional clues about whether particular artifacts or artifact assemblages are associated with ritual or play and, further, whether the play is that of adults, children, or both.

Both child and adult play are patterned activity, although, as with all human activity, they exhibit considerable variability at times. Play is patterned both within a particular culture and cross-culturally. The notion of a children's culture that is separable although closely intertwined with adult culture is well established (Jenkins 1998; Lancey 2008; Mouritsen and Qvortrup 2003). Thus, while as Langley and Litster point out, the clay dolls of Arnhem may look quite different from the ones made by Parakanã, within each culture there is a recognized format (or formats) for dolls. The same is true of games and play activities, suggesting that they will produce archaeologically identifiable clusters of objects or features. Within societies, children's cultures are recognizable and are often different from those of adults. Thus, even in something as central as gathering food, Bird and Bliege-Bird (2000) found that children and adults concentrated on different species.

Langley and Litster specifically mention the problem of differentiating unusual items used for ritual or magic from children's collections. They note that children often create collections of natural or cultural objects, perhaps from a psychological desire to impose control over some portion of the world. Not only children make collections, however. Adults, too, may curate the unusual; in fact, their collecting activities may sometimes border on the fanatical (Rubel and Rosman 2001). It is likely that there are cross-cultural differences between the types of objects collected by adults and children, and more study needs to be done on the difference between adult and child collecting habits, if any, so that these can be archaeologically identified.

Context should provide valuable information about the likelihood that we are seeing ritual and allowing us to differentiate between child and adult play. Beyond looking for contexts such as child burials or differentiating between household trash and ceremonial contexts, it is noteworthy that, cross-culturally, children tend to locate play activities in similar types of locales. Because children may seek autonomy from adult supervision, they frequently play on the fringes of adult activity (Baxter 2005a; Casey and Burruss 2010; Sánchez Romero et al. 2015). Nooks inaccessible to larger-sized adults are also often attractive play spaces for children, whether because of this very inaccessibility or because of the sensation that a child-sized world is discovered. Using cross-cultural data, Bradley (1993) demonstrates that children are often important parts of the economic system with culturally sanctioned duties, such as animal care. When this is so, children often also play where and while they work, leading to predictable spatial patterning.

Use-wear studies should also assist in differentiating between objects used for religious purposes and those serving as toys. In some cases, as with some miniature ceramics, we have ethnographic examples of objects used in ritual and other similar objects that served as toys. A comparison of the use wear on these would yield valuable clues to help archaeologists figure out ways of discerning which were used as toys and which were used for religion.

One additional important lesson from Langley and Litster's research goes well beyond the realm of either religion or childhood. They clearly show the inherent danger of essentializing either artifacts or components of artifacts. While archaeologists sometimes use a shorthand to associate specific activities, meanings, and users with artifact types, we all recognize that most objects are multiuse and that recycling and reuse routinely alter both the use and the identity of the user. Interpretation is particularly complex for multiuse items such as musical instruments or components of objects such as feathers, shells, or colorants.

\section{Grete Lillehammer}

Professor Emerita, Museum of Archaeology, University of Stavanger, N-4036 Stavanger, Norway (grete.lillehammer@uis.no). 10 X 17

\section{Why Adults?}

The disinterested discipline and negligence of children in the archaeological record is a familiar critique within the archaeology of childhood and beyond. In making their points clear, the authors argue that archaeology focuses on objects and patterns of economic and technological activity and neglects the rest of material culture or relegates the unexplained in the archaeological evidence to "ritual." Resourcefully, to overcome and con- 
tradict this stance they choose two analytic categories - ritual and play - to search for information that could prove helpful in distinguishing the agency of children in the consequences of actions manifested in the prehistoric archaeological record. Hence, the focus is set on the complex interrelationships between ritual and play. In this case it is the challenges of demonstrating appropriate materials that may distinguish children from adults in hunter-gatherer societies of the Ice Age.

The approach is a much-appreciated initiative to crossover studies of childhood and children in the past. To overcome gaps, build bridges, and enhance the understanding and interpretation of the archaeological materials of children from periods that lack both written and oral documentation, ethnographic analogy applies as method. The presentation is a systematic compilation, classification, and description of ethnographic examples of high significance and potentiality for the study of childhood in the past, and it is much welcomed. The illustrative review of data as well as literature spans from the deep past to the present. What it may take to make archaeological discoveries of children's playthings in practice underlines the argumentation. Compiled, cataloged, and presented here, the broad collection enlarges a whole set of new analytic categories and good points for further discussions.

Curiosity is a driving force in all good science, but does it restrict or hamper searches for a children's world in the past, or rather, turning the argument upside down: is this why it is difficult to distinguish children in the material evidence of the past and therefore science cannot see them properly? In the archaeology of childhood, these questions are essential and have been mulled back and forth from the very beginning of the research enterprise. The authors are in good company when asking the seemingly confusing questions, "Is it ritual? Or is it children?" In the afterword to the book Child's Play, on fantasy and the role of imagination in human existence, L. R. Goldman (1998:260) takes part in the clamor within anthropology that responds to such questions as "why child?" with "why adult?" Sufficient ethnographic materials indicate real diffusionary processes between adult and child dimensions of culture. Could the problem be a Western bias, with the English language and "children" as the universal analytical category of study and the separate class and population rather than the relational category inseparable from "parents" (Bird-Davis 2015:100)?

As children are mediators between worlds, economic and technologic approaches have been gateways to making new discoveries about children in the past (Lillehammer 2015). Considering children as contributors to livelihoods with duties and obligations from an early age, do archaeologists tend to see children as "little adults," the copycats playing along with parents, and oversee the runaway kids passing time away from grown-ups? The main problem here would seem to be distinguishing adult agency (ritual) from child agency (play). Archaeologists are acquainted with the ritual argument explaining the unexplained. It is a humorously phrased saying introduced to students early in their education and may well turn axiomatic into routine, thus erasing children's agency through adult-artifact pathways into the archaeological record (Crawford 2011). The consequence of ritual within the performative structure of child's play as a sequence or stage of process is something acknowledged by anthropologists (Schwartzman 1978). Ritual and play may overlap as well as the opposite; they may not go hand in hand.

The critique of archaeology requires a deeper and more precise definition of child's play in relationship with stages of development and learning from the natural and cultural environment. The authors present a definition of ritual as the manifestations of religious beliefs and take children and child's play for granted as universal facts of evolutionary and demographic consequence. They draw attention to a definition of child's play based on established types of play behavior and carry out observations of the ethnographic literature classifying the results. The use of historic or ethnographic analogy is one of the great challenges in archaeology filled with optimism and skepticism. Where to draw lines of the limits of archaeological interpretation about children's manifestations of agency and experience in the deep past would seem near at hand. Critical considerations on use/misuse of analogy and parallels from ethnography and history to reach an understanding of identities and social relations that scale the human past on a diversity of levels trigger types of interpretative approaches that form the basis for innovative models and working hypotheses. Child's play is an essential subcategory within the study of childhood in the past and a subject to hypothesis formation.

In the endeavour to understand and explain more about children in the past, a descriptive and comparative evaluation of the data potentiality is an uplifting step to the discovery of children in the archaeological record. Children's agency and their performative capacity demonstrate a great curiosity of the world, such as imitating adult activities and roles. However, more than copycats, children's worlds are their own creations. In the universe of make-believe, things are transformative and elusive. In the universe of materiality, playthings are multifunctional but are still material evidence. Therefore, a next step is doing tests of the results gained in the analysis initiating plans and participation in excavation projects that include a systematic exploration of similarities and differences in the material culture of children and adults among hunter-gatherers, also not forgetting all children of the past such as in semipastoral/semicultivator societies. What it takes to withstand disciplinary scepticism is to take up the stick and continue with the hard work. As simple as that — so why not do it.

\section{Marlize Lombard}

Centre for Anthropological Research, University of Johannesburg, Auckland Park 2006, South Africa (mlombard@uj.ac.za). 24 X 17

\section{What about an Evolutionary Perspective on Children's Object Play?}

Langley and Litster revisit the theme of turning to ritualistic interpretations for archaeological objects that could also have 
day-to-day explanations - arguing instead that some of these objects might be children's play objects. The distinctions between much of the material culture they present, however, might be equally ambiguous for either play or ritual. Ethnohistorical records certainly provide useful insight into recent forager behavior, potentially informing on objects linked to the children of the past. Yet for each ethnographic account attesting to items being used as play as opposed to ritual objects, there is probably an equally valid record to the contrary. African fertility dolls are but one such instance (e.g., Dell 1998).

It is also well known that Kalahari hunter-gatherer children are provided with scaled-down bow and arrow sets (see, e.g., Lee 1979; Liebenberg 1990; Lombard 2015; MacDonald 2007). Janette Deacon's (1992) synthesis, however, demonstrates the unquestionable role of truly "miniature" (much smaller than the play objects) bow and arrow sets in the intricate San belief systems. Today, in a different type of ritualized socio-economy, their descendants produce small bow sets, which are comparable to both play sets and ritual objects, for the tourist industry. Without known context and thorough analysis of artifacts within their particular settings, archaeologists therefore might remain challenged to distinguish child play from adult ritualespecially when similar objects were used during both performances.

Regarding ritual, I favor Radcliffe-Brown's (1952:144-152) inclusive definition, that is, "Ritual gives social value to artefacts and occasions by linking together people of a particular community in symbolical rites that in turn become essential to the maintenance of that society," compared to that used by Langley and Litster wherein ritual is seen as "habitual manifestations of religious beliefs" with or without material culture. The RadcliffeBrown definition is also more compatible with their argument that child play is a form of ritual. But I digress. ...

The neglect of children's object play in paleoarchaeology as highlighted by Langley and Litster might be because most archaeologists do not grapple with the theme in terms of biocultural theory/evolution (e.g., Kamp 2015). The authors touch on the potential of object play to inform on cognitive and symbolic behavioral evolution but then fail to unpack these themes, and references to key contributors on the topic are missing from their analysis (e.g., Nowell 2015a, 2015b, 2016; Nowell and White 2012). Because the artifacts of ritual and child play are so narrowly linked in their text, it might be difficult to use the contribution as a basis from which to generate convincing arguments about the importance of recognizing child play in the paleoarchaeological record.

I suggest that more robust evidence for children's object play can be gained by moving away from potential ritualistic objects to the more mundane. This is especially pertinent for deep-time explorations, where recent ethnographic analogies become diluted when not amplified with additional lines of evidence. Stone tools and their debitage are the most prolific "grammar" at the disposal of paleoarchaeologists with which to reconstruct narratives about past behaviors. Child play often mimics adult behaviors, also regarding subsistence and tech- nology — key drivers of human behavioral evolution. Thus, if we were able to detect children playing at knapping activities in the deep past, such observations could provide useful information about aspects such as ancient knowledge-transfer systems and cognition (e.g., Gärdenfors and Högberg 2017; Högberg and Larsson 2011; Högberg and Lombard 2016).

Useful theoretical bridges that might inform on Paleolithic children play-copying adult knapping activities can be found in experimental observations and in the Neolithic record (e.g., Högberg 2008; Milne 2005; Shelley 1990). For example, at a south Scandinavian Neolithic knapping site, where a squaresectioned flint ax-head was produced, Högberg (2008) concluded that alongside the master knapper, a child playfully produced an implement resembling that of the master. The ax-head production of the master could be recognized by the constrained distribution of debitage within a dedicated work space and a highly specialised, uniform technology based on selective raw material use. In contrast, the result of a child play-copying the master was evident in the haphazard distribution of debitage, the application of a nonsystematic technology, and the use of lowquality raw material. As a result, the child's object could never function as an ax-head, even though it roughly resembled the square-sectioned shape of the master's artifact.

The above suggests that older, Paleolithic, play-copying behavior can be traced by using variables such as the distribution of debris, systematic technology versus ad hoc technology, the use of high-quality (selective) raw materials versus low-quality (nonselective) raw materials, and typological forms (formal tools) versus nontypological forms (informal tools; Högberg 2008). It can also be expected that the "useful" products of a master will be removed from the knapping site, whereas those resulting from play-copying might be left behind (e.g., Karlin and Julien 1994). Of course, not all novice knappers were children (e.g., Finlay 1997). Provisioning children with the opportunity to gain knapping skills during play, however, would have had substantial evolutionary advantages and is therefore a plausible scenario. For example, it would ensure that by the time the young ones reached the necessary physical and cognitive aptitudes to master formal knapping, they would already have gained the necessary experience through object play to contribute meaningfully to a group's socio-economy, avoiding costly time-energy investment by apprenticing fully operational hunter-gatherers (Riede et al. 2018).

Meticulous analytical approaches, such as the Neolithic example above, enable archaeologists to reconstruct the material culture resulting from child play during deep time (e.g., Högberg and Larsson 2011). Coupling the archaeological evidence with life histories and evolutionary theory goes a long way to highlight the value of conducting increasingly robust research about the archaeology of paleo-children. For example, we have argued that encouraging children to play with objects is an integral part of Homo sapiens niche construction and that innovative phases in human prehistory might be linked to children's object play (Riede et al. 2018). Thus, seen in the light of niche-construction theory (where the behavior of organisms and how they modify 
their world have key evolutionary implications through the modification of selection pressures), paleo-child archaeology is elevated to more than diagnosing past child play.

\section{Reply}

We sincerely thank the commentators for their time and thoughts and are genuinely encouraged by the positivity in which our paper was received by some of the leading scholars in childhood or Paleolithic archaeology. We are grateful for the opportunity provided by this forum to promote dialogue on this topic and for the constructive points raised by our commentators.

In reading through the words of these researchers, we have identified a few points on which we would like to expand. First, we certainly agree that there is much work to be done to reduce the perceived ambiguity surrounding the identification of children's playthings from the deep past. The overlap between ritual objects and children's playthings presented in the ethnographic review serves to highlight this point - along with the hazards of categorizing objects. Indeed, the motivation for this study was the multifarious explanations for the presence of such "ritual" items in the archaeological record. We desire to not simply offer an alternative adage ("it's children!") but to encourage the exploration of other possibilities, especially those that consider children in the Paleolithic. We return shortly to how this ambiguity might be ameliorated and how such studies might proceed.

Second, we think it important to point out that our suggestion that at least some of the numerous portable artworks produced during the Upper Paleolithic of Europe (for example) may reflect children's activities - rather than adult-centered religious rituals - is not made to move these beautiful items away from more mainstream discussions of their artistic importance but rather to encourage archaeologists to reconsider even the most archaeologically "precious" items. For example, even if in the future we were able to conclusively demonstrate that the famous Aurignacian lion-man (Löwenmensch) of Hohlenstein-Stadel, Germany, was a child's doll, this identification would not detract from its significance as the oldest-known zoomorphic figurine found nor its importance for studying the origins and development of European Paleolithic art. Being made for and used by a child does not necessarily equal mundane and unimportant. Similarly, being owned by a child also does not completely rule out any and all ritual connotations. As argued by Nowell (2015b), many examples of Upper Paleolithic art are perfect for "fantasy play" - that which develops creativity, behavioral plasticity, imagination, and planning - and thus, portable art such as the figurines may have been perfect for children exploring spiritual knowledge and its role in their community. This idea is yet another avenue for researchers to pursue.

On mentioning the study of the more "mundane," Lombard calls for an emphasis on such things as knapping activities and the use of experimental observation to understand children's play in the deep past. While we agree that experimental work will be of much use in understanding past play behaviors, focusing on the mundane unnecessarily limits our scope, and we contend that multiple approaches will lead to the most robust understanding of past children, childhood, and humanity possible. Furthermore, it should be noted that the identification of children in prehistoric sites - outside of burials and rock arthas been mainly focused on the transmission of craft knowledge. While most commonly explored in lithic studies (e.g., Bodu, Karlin, and Ploux 1990; Grimm 2000; Olive 1988; Pigeot 1990; Shea 2006), recent work has looked at identifying apprentice artists (e.g., Fritz 1999a, 1999b; Fritz, Tosello, and Conkey 2015; Nowell 2015a; Rivero 2016; Russell 1989). While these studies certainly contribute information regarding the activities and education of children in the past, they do tend to consider the prehistoric child in terms of "what she is subsequently going to be rather than what she presently is" (Goodwin 1997:1). It is this observation that led us to focus on children doing what children do best - play. And the material culture of play is playthings. We hope that by showing the enormous overlap between common playthings in hunter-gatherer societies we have demonstrated the importance and feasibility of focusing on finding children not only in the mundane (lithic and other technological or subsistence analyses) but also in the imaginative.

It is also important that we not remove agency from children. While it is true that adults can and did play a large role in the material culture that came into the hands of children, as raised by Bar-Yosef Mayer, it is equally true that children also gathered and made their own playthings - completely away from adult eyes (Crawford 2009). As Lillehammer points out, it is this time spent away from adults that might have been dismissed by studies that depicted them as "little adults," focusing instead on learning and imitation behaviors. Consequently, we feel it important to avoid automatically returning objects identifiable to children to the actions of an adult. Furthermore, it should be remembered that "toys are given significance and meaning by the children who play with them" (Crawford 2009:57).

Several scholars also discussed the manner in which we had distinguished children from adults and ritual from play. As identified in the paper and in several of the comments, adults participate in behavior similar to children — such as caching and games. Here we divided children and adults in an attempt to rebut categories routinely presented by archaeologists. It is also for this reason that we have distinguished ritual from social ritual—which we acknowledge includes play.

Importantly, and as Lillehammer raises, there are arguments for and against the use of the ethnographic analogy in such studies, which we acknowledge (Wiley 1985). The parallels we aimed to draw were behaviors seen universally and not from individual cultural and historical contexts.

We wholeheartedly agree with Kamp and Lillehammer in that the next necessary steps required to undertake meaningful inquiries into identifying children and exploring their childhood in the deep past will entail additional ethnoarchaeological re- 
search beyond what we have presented, for example, specific studies on the collecting behaviors of children cross-culturally. These aspects should be explored in conjunction with use-wear studies and experimental observations (among other approaches), which when combined with results gained from systematic analyses of purported and known ritual and play objects will no doubt point the way for future understandings. We are in fact already delving into whether patterns of use wear on modern children's figurines (and other playthings) might be useful in identifying similar items from prehistory.

In summary, we feel that the types of research discussed in this forum will benefit not only childhood studies but also those focused more on exploring the past ritual and religious aspects of humanity across the globe. Given the impact such insights might further have on our understanding of human evolution, it is imperative that we not fall into a state of protracted ambivalence. As Baxter so succinctly outlined, there is much to be said for the virtues of "staying with a problem longer."

- Michelle C. Langley and Mirani Litster

\section{References Cited}

Acher, R. A. 1910. Spontaneous constructions and primitive activities of children analogous to those of primitive man. American Journal of Psychology 21:114150.

Anderson, Steven, Hanna Damasio, and Antonio R. Damasio. 2005. A neural basis for collecting behavior in humans. Brain 128:201-202.

Arias, Pablo. 2009. Rites in the dark? an evaluation of the current evidence for ritual areas at Magdalenian cave sites. World Archaeology 41:262-294.

Arima, E. Y. 1984. Caribou Eskimo. In Arctic, vol. 5 of Handbook of North American Indians. D. Damas, ed. Pp. 447-462. Washington, DC: Smithsonian Institution.

Arima, E. Y., and J. Dewhirst. 1990. Nootkans of Vancouver Island. In Northwest Coast, vol. 7 of Handbook of North American Indians. W. Suttles, ed. Pp. 391 411. Washington, DC: Smithsonian Institution.

Aström, L., and D. S. Reese. 1990. Triton shells in east Mediterranean cults. Journal of Prehistoric Religion 3:5-14.

Bahn, Paul. 1982. Inter-site and inter-regional links during the Upper Palaeolithic: the Pyrenean evidence. Oxford Journal of Archaeology 1:247-268.

. 2012. Religion and ritual in the Upper Palaeolithic. In The Oxford handbook of the archaeology of ritual and religion. T. Insoll, ed. Oxford: Oxford Handbooks Online. doi:10.1093/oxfordhb/9780199232444.013.0023.

Bahn, Paul, and Jean Vertut. 1988. Images of the Ice Age. Leicester: Windward.

Balikci, A. 1984. Netsilik. In Arctic, vol. 5 of Handbook of North American Indians. D. Damas, ed. Pp. 415-430. Washington, DC: Smithsonian Institution.

Banfield, Edmund. 1911. My tropic isle. London: Unwin.

Bar-Yosef Mayer, D. E. 2013. Mollusc exploitation at Çatalhöyük. In Humans and landscapes of Çatalhöyük: reports from the 2000-2008 seasons, vol. 8 of Çatalhöyük research project. I. Hodder, ed. Pp. 329-338. Los Angeles: Cotsen Institute of Archaeology. [DEB-YM]

Basso, K. H. 1983. Western Apache. In Southwest, vol. 10 of Handbook of North American Indians. A. Ortiz, ed. Pp. 462-488. Washington, DC: Smithsonian Institution.

Bates, D. M. n.d. Games [and] amusements. From section 11, part 4a, manuscript at the National Library (MS 365, folio 36, 88-117, on microfilm G 24,000-710).

Baxter, Jane Eva. 2005a. The archaeology of childhood: children, gender, and material culture. Walnut Creek, CA: AltaMira.

2005b. Introduction: the archaeology of childhood in context. $A r-$ chaeological Papers of the American Anthropological Association 15:1-9.

Bednarik, Robert. 1995. Concept-mediated marking in the Lower Palaeolithic Current Anthropology 36:605-634.

. 2014. Paleoart of the Lower Paleolithic. Progress in Arts and $\mathrm{Hu}$ manities 1:1-12.

Bégouën, Max. 1926. Bison of clay. London: Longmans, Green.
Bégouën, R., and J. Clottes. 1980. Apports mobiliers dans les cavernes du Volp (Enlène, les Trois Frères, le Tuc d'Audoubert). In Altamira symposium. M. Almagro, ed. Pp. 157-188. Madrid: Ministerio de la Cultura.

Bégouën, R., C. Fritz, G. Tosello, J. Clottes, A. Pastoors, and F. Faist. 2009. Le sanctuaire secret des bisons. Paris: Somogy.

Best, Elsdon. 1925. Games and pastimes of the Maori. Dominion Museum Bulletin no. 8. Wellington, New Zealand: Whitcombe \& Tombs.

Bichara, Ilka Dias. 1999. Brincadeira e cultura: o faz-de-conta das crianças Xocó e do Mocambo. Temas em Psicologia 7:57-64.

Binford, Lewis. 1978. Nunamiut ethnoarchaeology. New York: Academic Press. Bird, Douglas, and Rebecca Bliege-Bird. 2000. The ethnoarchaeology of juvenile foragers: shellfishing strategies among Meriam children. Iournal of Anthropological Archaeology 19:461-476.

Bird-Davis, Nurit. 2015. Modern biases, hunter-gatherers' children: on the visibility of children in other cultures. In The archaeology of childhood: interdisciplinary perspectives on an archaeological enigma, vol. 4 of IEMA proceedings. Güner Coşkunsu, ed. Pp. 91-103. Albany: State University of New York Press.

Birket-Smith, Kaj. 1929. The caribou Eskimos. 1. Descriptive part, vol. 5 of Report of the fifth Thule expedition 1921-24. Copenhagen: Gyldendalske.

Blanc, Alberto. 1957. A new Paleolithic cultural element, probably of ideological significance: the clay pellets of the cave of Basua (Savona). Quaternaria 4:1-9.

Bleek, D. F. 1928. The Naron: a Bushman tribe of the Central Kalahari. Cambridge: Cambridge University Press.

Bloch, M., and A. Pelligrini. 1989. Ways of looking at children, context, and play. In The ecological context of children's play. M. Bloch and A. Pellegrini, eds. Pp. 1-15. Norwood, NJ: Ablex.

Bodu, P., C. Karlin, and S. Ploux. 1990. Who's who? the Magdalenian flintknappers of Pincevent, France. In The big puzzle: International Symposium on Refitting Stone Artefacts. E. Cziesla, S. Eickhoff, N. Arts, and D. Winter, eds. Pp. 143-163. Bonn: Holos.

Boivin, Nicole. 2009. Grasping the elusive and unknowable: material culture in ritual practice. Material Religion 5:266-287.

Bonnichsen, Robson. 1973. Millie's camp: an experiment in archaeology. World Archaeology 4(3):277-291.

Bradley, Candice. 1993. Women's power, children's labor. Cross-Cultural Research 27:70-96. [KK]

Breuil, Abbé. 1952. Quatre cents siècles d'art pariétal. Montignac: Centre d'Études et de Documentation Préhistoriques.

Briggs, Jean. 1974. Eskimo women: makers of men. In Many sisters: women in crosscultural perspective. C. J. Matthiasson, ed. Pp. 261-304. New York: Free Press.

Brough-Smyth, Robert. 1878. The aborigines of Victoria: with notes relating to the habits of natives of other parts of Australia and Tasmania. Melbourne: Ferres.

Bugarin, Flordeliz. 2005. Constructing an archaeology of children: studying children and child material culture from the African past. Archaeological Papers of the American Anthropological Association 15:13-26.

Burch, E. S. 1984. Kotzebue Sound Eskimo. In Arctic, vol. 5 of Handbook of North American Indians. D. Damas, ed. Pp. 303-319. Washington, DC: Smithsonian Institution.

Burke, Heather, Susan Arthure, and Cherrie de Leiuen. 2016. A context for concealment: the historical archaeology of folk ritual and superstition in Australia. International Journal of Historical Archaeology 20:45-72.

Burton Jones, N. 1993. The lives of hunter-gatherer children: effects of parental behavior and parental reproductive strategy. In Juvenile primates: life history, development, and behavior. M. E. Pereira and L. A. Fairbanks, eds. Pp. 309-326. Chicago: University of Chicago Press.

Caldwell, Duncan. 2009. Palaeolithic whistles or figurines? a preliminary survey of pre-historic phalangeal figurines. Rock Art Research 26:65-82.

Callaway, D., J. Janetski, and O. C. Stewart. 1986. Ute. In Great Basin, vol. 11 of Handbook of North American Indians. W. L. d'Azevedo, ed. Pp. 336-367. Washington, DC: Smithsonian Institution.

Casey, Joanna, and Rachele Burruss. 2010. Social expectations and children's play places in northern Ghana. Ethnoarchaeology 2:49-72. [KK]

Chamberlain, A. T. 1997. Commentary: missing stages of life: towards the perception of children in archaeology. In Invisible people and processes: writing gender and childhood into European archaeology. J. Moore and E. Scott, eds. Pp. 248-250. London: Taylor \& Francis.

Chase, Philip G., and Harold L. Dibble. 1987. Middle Paleolithic symbolism: a review of current evidence and interpretations. Journal of Anthropological Archaeology 6:263-296.

Child, Daphne. 1969. Yesterday's children. Cape Town: Timmins. 
Chipeniuk, Raymond. 1995. Childhood foraging as a means of acquiring competent human cognition about biodiversity. Environment and Behavior 27:490-512.

Cichocki, Otto, Bernhard Knibbe, and Isabella Tillich. 2014. Archaeological sig nificance of the Palaeolithic charcoal assemblage from Krems-Wachtberg Quaternary International 351:163-171.

Clark, D. W. 1984. Pacific Eskimo: historical ethnography. In Arctic, vol. 5 of Handbook of North American Indians. D. Damas, ed. Pp. 185-197. Washington, DC: Smithsonian Institution.

Clastres, Pierre. 1988. A sociedade contra o estado: pesquisa de antropologia política. São Paulo: Cosac \& Naify.

Clifton, J. A. 1978. Potawatomi. In Northwest, vol. 15 of Handbook of North American Indians. B. G. Trigger, ed. Pp. 725-742. Washington, DC: Smithsonian Institution.

Clot, André. 1987. La Grotte de Gerde (Hautes-Pyrénées), site préhistorique et paléontologique. Bagnères-de-Bigorre: Société Ramond.

Clottes, Jean. 1997. Art of the light and art of the depths. In Beyond art: Pleistocene image and symbol. M. Conkey, O. Soffer, D. Stratmann, and N. G. Jablonski, eds. Pp. 203-216. Berkeley: University of California Press.

Clottes, Jean, Jean Courtin, and Luc Vanrell. 2005. Prehistoric images and medicines under the sea. International Newsletter on Rock Art 42:1-8.

Cohn, Clarice. 2002. A experiência da infáncia e o aprendizado entre os Xikrin. In Crianças Indígenas: ensaios antropológicos. A. L. Silva, A. V. L. S. Macedo, and A. Nunes, eds. Pp. 117-149. São Paulo: Global.

Conard, Nicholas J. 2003. Palaeolithic ivory sculptures from southwest Germany and the origins of figurative art. Nature 426:830-832.

Cooper, J. M. 1949. Games and gambling. In Handbook of South American Indians: the comparative ethnology of South American Indians. J. H. Steward, ed. Pp. 503-524. Washington, DC: US Government Printing Office.

Coşkunsu, G., ed. 2015. The archaeology of childhood: interdisciplinary perspectives on an archaeological enigma, vol. 4 of the Institute for European and Mediterranean Archaeology Distinguished Monograph Series. Albany, NY: SUNY Press. [DEB-YM]

Cox, James C. 1888. Notes on two wax figures obtained from an Aboriginal camp at Miriam Vale near the head of Baffle Creek, Rockhampton. Proceedings of the Linnean Society of New South Wales 13:1223-1226.

Crawford, Sally. 2009. The archaeology of play things: theorising a toy stage in the "biography" of objects. Childhood in the Past 2:55-70.

- 2011. Overview: the body and life course. In The Oxford handbook of Anglo-Saxon archaeology. D. A. Hinton, S. Crawford, and H. Hamerow, eds. Pp. 625-640. Oxford: Oxford University Press.

Cunnar, Geoffery E., and Anders Höberg, eds. 2015. The child is now 25. Special issue, Childhood in the Past 8(2). [JEB]

Damas, D. 1984. Copper Eskimo. In Arctic, vol. 5 of Handbook of North American Indians. D. Damas, ed. Pp. 397-414. Washington, DC: Smithsonian In stitution.

Danet, Brenda, and Tamar Katriel. 1994. Glorious obsessions, passionate lovers, and hidden treasures: collecting, metaphor and romantic ethic. In The socialness of things: essays on the socio-semiotics of objects. S. H. Riggins, ed. Pp. 23 62. New York: Mouton de Gruyter.

Dawson, James. 1881. Australian aborigines: the languages and customs of several tribes of aborigines in the Western Desert of Victoria, Australia. Sydney: Robertson.

Day, G. M. 1978. Western Abenaki. In Northwest, vol. 15 of Handbook of North American Indians. B. G. Trigger, ed. Pp. 148-159. Washington, DC: Smithsonian Institution.

d'Azevedo, W. L. 1986. Washoe. In Great Basin, vol. 11 of Handbook of North American Indians. W. L. d'Azevedo, ed. Pp. 466-498. Washington, DC: Smithsonian Institution.

Deacon, H. J. 2001. Modern human emergence: an African archaeological perspective. In Humanity from African naissance to coming millennia: colloquia in human biology and palaeoanthropology. P. V. Tobias, M. A. Raath, J. MaggiCecchi, and G. A. Doyle, eds. Pp. 217-226. Florence: University of Florence Press.

Deacon, Janette. 1992. Arrows as agents of belief amongst the /Xam Bushmen. Margaret Shaw Lecture 3. Cape Town: National Monuments Council. [ML]

Dell, E. 1998. Evocations of the child: fertility figures of the southern African region. London: Lund Humphries. [ML]

de Maret, Pierre. 2016. Bones, sex, and dolls: solving a mystery in Central Africa and beyond. Iournal of Field Archaeology 41:500-509.

Demars, Pierre-Yves. 1992. Les colorants dans le Moustérien du Périgord: l'apport des fouilles de F. Bordes. Préhistoire Ariégeoise 47:185-194.
d'Errico, Francesco. 2003. The invisible frontier: a multiple species model for the origin of behavioral modernity. Evolutionary Anthropology 12:188-202. d'Errico, Francesco, Claire Gaillard, and Virendra N. Misra. 1989. Collections of non-utilitarian objects by Homo erectus in India. In Hominidae: Proceedings of the 2nd International Congress of Human Paleontology. G. Giacohini, ed. Pp. 237-239. Milan: Jaca Book.

d'Errico, Francesco, Christopher Henshilwood, Graeme Lawson, Marian Vanhaeren, Ann-Marie Tillier, Marie Soressi, Frédérique Bresson, et al. 2003. Archaeological evidence for the emergence of language, symbolism, and musican alternative multidisciplinary perspective. Iournal of World Prehistory 17:1-70.

d'Errico, Francesco, Christopher Henshilwood, Marian Vanhaeren, and Karen van Niekerk. 2005. Nassarius kraussianus shell beads from Blombos Cave: evidence for symbolic behaviour in the Middle Stone Age. Lournal of Human Evolution 48:3-24.

Dickau, Ruth, Steward D. Redwood, and Richard G. Cooke. 2013. A 4,000year-old shaman's stone cache at Casita de Piedra, western Panama. Archaeological and Anthropological Sciences 5:331-349.

Doke, C. M. 1937. Games, plays, and dances of the $\$$ Khomani Bushman. In Bushmen of the southern Kalahari. J. D. Rheinallt Jones and C. M. Doke, eds. Pp. 89-99. Johannesburg: University of Witwaterstrand Press.

Dornan, S. S. 1925. Pygmies and Bushmen of the Kalahari. London: Sealy.

Dozier, Crystal A. 2016. Finding children without toys: the archaeology of children at Shabbona Grove, Illinois. Childhood in the Past 9:58-74.

Draper, Patricia. 1976. Social and economic constraints on child life among the !Kung. In Kalahari hunter-gatherers: studies of the !Kung San and their neighbors. R. B. Lee and I. DeVore, eds. Pp. 199-217. Cambridge, MA: Harvard University Press.

Eibl-Eibesfeldt, Irenäus. 1989. Human ethology: origins and prospects of a new discipline. In New aspects of human ethology. A. Shmitt, K. Atzwanger, K. Grammer, and K. Schäfter, eds. Pp. 1-24. New York: Plenum.

Elsasser, A. B. 1978a. Development of regional prehistoric cultures. In California, vol. 8 of Handbook of North American Indians. R. F. Heizer, ed. Pp. 37-57. Washington, DC: Smithsonian Institution.

. 1978b. Mattole, Nongatl, Sinkyone, Lassik, and Wailaki. In California, vol. 8 of Handbook of North American Indians. R. F. Heizer, ed. Pp. 190-204. Washington, DC: Smithsonian Institution.

Ember, Carol R., and Christiane M. Cunnar. 2015. Children's play and work: the relevance of cross-cultural ethnographic research for archaeologists. Childhood in the Past 8:87-103.

Emslie, Steven. 1987. A desert culture shrine in Grand Canyon, Arizona, and the role of split-twig figurines. National Geographic Research 3:511-516.

Endicott, Kirk. 1979. Batek Negrito religion: the world-view and rituals of a hunting and gathering people of Peninsular Malaysia. Oxford: Clarendon.

Euler, Robert, and Alan Olsen. 1965. Split-twig figurines from northern Arizona: new radiocarbon dates. Science 148:368-369.

Evans, Ian. 2010. Touching magic: deliberately concealed objects in old Australian houses and buildings. $\mathrm{PhD}$ thesis, University of Newcastle.

Eyre, Edward. 1845. Journals of the expeditions of discovery into Central Australia and overland from Adelaide to Kin Georges Sound, manners and customs of the aborigines of Australia. London: Boone.

Finlay, N. 1997. Kid knapping: the missing children in lithic analysis. In Invisible people and processes: writing gender and childhood into European archaeology. J. Moore and E. Scott, eds. Pp. 203-212. London: Leicester University Press. [ML]

Finlayson, Clive, Kimberley Brown, Ruth Blasco, Jordi Rosell, Juan José Negro, Gary R. Bortolotti, Geraldine Finlayson, et al. 2012. Birds of a feather: Neanderthal exploitation of raptors and corvids. PLoS ONE 7:e45927.

Firth, Raymond. 1970. We, the Tikopia: a sociological study of kinship in primitive Polynesia. Boston: Beacon.

Flannery, Regina. 1953. Social life, part 1 of The Gros Ventres of Montana. Washington, DC: Catholic University of America Press.

Fowler, C. S., and S. Liljeblad. 1986. Northern Paiute. In Great Basin, vol. 11 of Handbook of North American Indians. W. L. d'Azevedo, ed. Pp. 435-465. Washington, DC: Smithsonian Institution.

Foxhall, Lin. 2015. Introduction: miniaturization. World Archaeology 47(1): $1-5$.

Freeman, L. G., J. Gonzalez Eschegarary, F. Bernaldo de Quiros, and J. Ogden. 1987. Altamira revisited. Chicago: Institute for Prehistoric Investigations.

Freikman, Michael, and Yosef Garfinkel. 2009. The zoomorphic figurines from Sha'ar Hagolan: hunting magic practices in the Neolithic Near East. Levant 41:5-17. 
Fritz, Carole. 1999a. La gravure dans l'art mobilier Magdalénien: du geste à la représentation. Paris: Éditions de la Maison des sciences.

- 1999b. Towards a rebuilding of the Magdalenian artistic processes: the use of microscopic analysis in the field of miniature art. Cambridge Archaeological Journal 9:189-208.

Fritz, Carole, Gilles Tosello, and Margaret W. Conkey. 2015. Reflections on the identities and roles of the artists in European Palaeolithic societies. Journal of Archaeological Method and Theory 23:1307-1332.

Fry, D. P. 2005. Rough-and-tumble social play in humans. In The nature of play: great apes and humans. A. D. Pellegrini and P. K. Smith, eds. Pp. 54-85. London: Guilford.

Gärdenfors, P., and A. Högberg. 2017. The archaeology of teaching and the evolution of Homo docens. Current Anthropology 58:188-208. [ML]

Geertz, Clifford. 1973. The new interpretation of cultures. New York: Basic.

Gilmore, Mary. 1934. Old days, old ways: a book of recollections. Sydney: Angus \& Robertson.

Goddard, I. 1978. Delaware. In Northeast, vol. 15 of Handbook of North American Indians. B. G. Trigger, ed. Pp. 213-239. Washington, DC: Smithsonian Institution.

Goldman, L. R. 1998. Child's play: myth, mimesis and make-believe. Oxford: Berg. [GL]

Goldman, Laurence R., and Michael Emmison. 1995. Make-believe play among Huli children: performance, myth, and imagination. Ethnology 34:225255.

Gómez, Juan-Carlos, and B. Martin-Andrade. 2005. Fantasy play in apes. In The nature of play: great apes and humans. A. D. Pellegrini and P. K. Smith, eds. Pp. 139-172. New York: Guilford.

Goodwin, Astley. 1945. Some historical Bushman arrows. South African Journal of Science 41:429-443.

Goodwin, M. H. 1997. Children's linguistic and social worlds. Anthropology Newsletter 38:4-5.

Gopher, Avi, and Estelle Orrelle. 1996. An alternative interpretation for material imagery of the Yarmukian, a Neolithic culture of the sixth millennium BC in the Southern Levant. Cambridge Archaeological Journal 6:255-279.

Goren-Inbar, N., Z. Lewy, and M. E. Kislev. 1991. Bead-like fossils from an Acheulean occupation site, Israel. Rock Art Research 8:133-135.

Gosso, Y., and E. Otta. 2003. Em uma aldeia Parakanã. In Brincadeira é cultura: viajando pelo Brasil que brinca. A. M. A. Carvalho, C. M. C. Magalhães, F. A. R. Pontes, and I. D. Bichara, eds. Pp. 33-76. São Paulo: Casa do Psicólogo.

Gosso, Y., E. Otta, M. de Lima Salum e Morais, F. J. Leite Ribeiro, and V. S. Raad Bussab. 2005. Play in hunter-gatherer society. In The nature of play: great apes and humans. A. D. Pellegrini and P. K. Smith, eds. Pp. 213-253. London: Guilford.

Gould, Richard A. 1970. Spears and spear-throwers of the Western Desert aborigines of Australia. American Museum Novitates 2403:1-42.

Gregor, Thomas. 1982. Mehináku: o drama da vida diária em uma aldeia do Alto Xingu. São Paulo: Nacional.

Grimm, Linda. 2000. Apprentice flintknapping: relating material culture and social practice in the Upper Paleolithic. In Children and material culture. J. Sofaer Derevenski, ed. Pp. 53-71. New York: Routledge.

Grinnell, George. 1923. The Cheyenne Indians: their history and ways of life. New Haven, CT: Yale University Press.

Guemple, Lee. 1979. Inuit socialization: a study of children as social actors in an Eskimo community. In Childhood and adolescence in Canada. I. Karigoudar, ed. Pp. 39-71. Toronto: McGraw-Hill.

Guise, R. E. 1899. On the tribes inhabiting the mouth of the Wanigela River, New Guinea. Iournal of the Anthropological Institute of Great Britain and Ireland 28:205-219.

Haagen, Claudia. 1994. Bush toys: Aboriginal children at play. Canberra: Aboriginal Studies.

Haddon, Alfred Cort. 1912. Reports of the Cambridge anthropological expedition to Torres Straits 4. Cambridge: Cambridge University Press.

Hadingham, Evan. 1979. Secrets of the Ice Age: the world of the cave artists. New York: Walker.

Hamilton, Annette. 1981. Nature and nurture: Aboriginal child-rearing in northcentral Arnhem Land. Canberra: Australian Institute of Aboriginal Studies.

Händel, Marc, Thomas Einwögerer, Ulrich Simon, and Christine NeugebauerMaresch. 2014. Krems-Wachtberg excavations 2005-12: main profiles, sampling, stratigraphy, and site formation. Quaternary International 351:3849.

Hawkes, Christopher. 1954. Archaeological theory and method: some suggestions from the Old World. American Anthropologist 56:155-168.
Helms, Richard, and W. Paterson. 1896. Anthropology, report of the Elder Scientific Expedition, 1891. Transactions of the Royal Society of South Australia 16:237-332.

Hernández, Theodore. 1941. Children among the Drysdale River tribes. Oceania 12:122-133.

Hodder, Ian. 1982. Symbols in action: ethnoarchaeological studies of material culture. Cambridge: Cambridge University Press.

Högberg, A. 2008. Playing with flint: tracing a child's imitation of adult work in a lithic assemblage. Lournal of Archaeological Method Theory 15:112-131. [ML]

Högberg, A., and L. Larsson. 2011. Lithic technology and behavioural modernity: new results from the Still Bay site, Hollow Rock Shelter, Western Cape Province, South Africa. Iournal of Human Evolution 61:133-155. [ML]

Högberg, A., and M. Lombard. 2016. Still Bay point-production strategies at Hollow Rock Shelter and Umhlatuzana Rock Shelter and knowledge-transfer systems in southern Africa at about 80-70 thousand years ago. PLoS ONE 11 (12):e0168012. doi:10.1371/journal.pone.0168012. [ML]

Honigmann, J. J. 1981. West Main Cree. In Subarctic, vol. 6 of Handbook of North American Indians. J. J. Honigmann, ed. Pp. 217-230. Washington, DC: Smithsonian Institution.

Howitt, A. W. 1904. The native tribes of south-east Australia. London: Macmillan. Hughes, C. C. 1984a. Saint Lawrence Island Eskimo. In Arctic, vol. 5 of Handbook of North American Indians. D. Damas, ed. Pp. 262-277. Washington, DC: Smithsonian Institution.

. 1984b. Siberian Eskimo. In Arctic, vol. 5 of Handbook of North American Indians. D. Damas, ed. Pp. 247-261. Washington, DC: Smithsonian Institution.

Hurst Thomas, D., L. S. A. Pendleton, and S. C. Cappannari. 1986. Western Shoshone. In Great Basin, vol. 11 of Handbook of North American Indians. W. L. d'Azevedo, ed. Pp. 262-283. Washington, DC: Smithsonian Institution. Ibáñez, Juan José, Jesús Salius, Ignacio Clemente-Conte, and Narcis Soler. 2015. Use and sonority of a 23,000-year-old bone aerophone from Davant Pau Cave (NE of the Iberian Peninsula). Current Anthropology 56:282-289.

Insoll, Tim. 2004. Archaeology, ritual, religion. London: Routledge.

2009. Materiality, belief, ritual-archaeology and material religion: an introduction. Material Religion 5(3):260-265.

. 2012. The Oxford handbook of the archaeology of ritual and religion. Oxford: Oxford University Press.

Jaubert, Jacques, Sophie Verheyden, Dominique Genty, Michael Soulier, Hai Cheng, Dominique Blamart, Christian Burlet, et al. 2016. Early Neanderthal constructions deep in Bruniquel Cave in southwestern France. Nature 534: 111-115.

Jenkins, Henry, ed. 1998. The children's culture reader. Albany: New York University Press. [KK]

Jenness, D. 1922. The life of the Copper Eskimos, vol. 12 of Ottawa: report of the Canadian Arctic expedition, 1913-18. Ottawa: Acland.

Jett, Stephen C. 1987. Additional information on split-twig and other willow figurines from the greater Southwest. American Antiquity 52:392-396.

. 1991. Split-twig figurines, early maize, and a child burial in eastcentral Utah. Utah Archaeology 4:23-31.

Johnson, Matthew. 2010. Archaeological theory. an introduction. Oxford: Wiley.

Kahlenberg, S. M., and R. W. Wrangham. 2010. Sex differences in chimpanzees' use of sticks as play objects resemble those of children. Current Biology 20(24): R1067-R1068. [AB]

Kamp, Kathryn A. 2001. Where have all the children gone? the archaeology of childhood. Lournal of Archaeological Method and Theory 8:1-34.

. 2015. Children and their childhoods: retrospectives and prospectives. Childhood in the Past 8(2):161-169.

Kamp, Kathryn A., Nichole Timmerman, Gregg Lind, Jules Graybill, and Ian Notowsky. 1999. Discovering childhood: using fingerprints to find children in the archaeological record. American Antiquity 64:309-315.

Karlin, C., and M. Julien. 1994. Prehistoric technology: a cognitive science? In The ancient mind: elements of cognitive archaeology. C. Renfrew and E. B. W. Zubrow, eds. Pp. 152-164. Cambridge: Cambridge University Press. [ML]

Karlin, C., and N. Pigeot. 1989. Chasseurs-cueilleurs Magdaléniens: l'apprentissage de la taille silex. Courier du CNRS (Dossiers Scientifiques) 73:10-12.

Kelly, I. T., and C. S. Fowler. 1986. Southern Paiute. In Great Basin, vol. 11 of Handbook for North American Indians. W. L. d'Azevedo, ed. Pp. 368-397. Washington, DC: Smithsonian Institution.

Kennedy, D. I. D., and R. T. Bouchard. 1990. Bella Coola. In Northwest Coast, vol. 7 of Handbook for North American Indians. W. Suttles, ed. Pp. 323-339. Washington, DC: Smithsonian Institution. 
Kennedy, Eliza, and Tamsin Donaldson. 1982. Coming up out of the Nhaalya: reminiscences of the life of Eliza Kennedy. Aboriginal History 6:5-27.

Kleivan, I. 1984. West Greenland before 1950. In Arctic, vol. 5 of Handbook of North American Indians. D. Damas, ed. Pp. 595-621. Washington, DC: Smithsonian Institution.

Koerper, Henry C., Nancy Anastasia Desautels, and Jeffrey S. Couch. 2002. Quartz crystals and other sparkling minerals from the Bolsa Chica Archaeological Project. Pacific Coast Archaeological Society Quarterly 38(4):61-83.

Kuhn, Steven L., and Mary C. Stiner. 2007. Paleolithic ornaments: implications for cognition, demography and identity. Diogenes 214:40-48.

Lancy, David F. 2008. The anthropology of childhood: cherubs, chattel, changelings. Cambridge: Cambridge University Press. [KK]

Lane, Cyril Grant. 1915. Adventures in the big bush: in the haunts of the Aboriginal. London: Hutchinson.

Leacock, E. 1976. At play in African villages. In Play: its role in development and evolution. J. S. Bruner, A. Jolly, and K. Sylva, eds. Pp. 466-473. London: Penguin.

Lee, R. 1979. The !Kung San: men, women and work in a foraging society. Cambridge: Cambridge University Press. [ML]

Lekies, Kristi S., and Thomas H. Beery. 2013. Everyone needs a rock: collecting items from nature in childhood. Children, Youth, and Environments 23:66-88.

Leroi-Gourhan, André. 1964. Les religions de la préhistoire: Paléolithique. Paris: Presses Université de France.

. 1967. Treasures of prehistoric art. New York: Abrams.

. 1968. The art of prehistoric man in western Europe. London: Thames \& Hudson.

Lewis, Kerrie P. 2005. Social play in the great apes. In The nature of play: great apes and humans. A. D. Pellegrini and P. K. Smith, eds. Pp. 27-53. London: Guilford.

Lewis-Williams, David. 2002. The mind in the cave. London: Thames \& Hudson.

L'Homme, V., and S. Freneix. 1993. Un coquillage de bivalve du Maastrichtienpaléocène Glyptoacis (Baluchicardia) sp. dans la couche inférieure du gisement moustérien de "Chez-Pourré-Chez-Comte» (Corrèze). Bulletin de la Société Préhistorique Française 90:303-306.

Liebenberg, L. 1990. The art of tracking. Cape Town: Philip. [ML]

Lillehammer, Grete. 1989. A child is born: the child's world in an archaeological perspective. Norwegian Archaeological Review 22:89-105.

. 2015. 25 years with the "child" and the archaeology of childhood. Childhood in the Past 8(2):78-86. [GL]

Loeb, E. M. 1928. Mentawei social organisation. American Anthropologist 30:408433.

Lombard, M. 2015. Hunting and hunting technologies as proxy for teaching and learning during the Stone Age of southern Africa. Cambridge Archaeological Journal 25:877-887. [ML]

Love, James. 1936. Stone-Age bushmen of today: life and adventure among a tribe of savages in north-western Australia. London: Blackie.

Luomala, K. 1978. Tipai-Ipai. In California, vol. 8 of Handbook of North American Indians. R. F. Heizer, ed. Pp. 592-609. Washington, DC: Smithsonian Institution.

MacDonald, K. 2007. Cross-cultural comparison of learning in human hunting implications for life history evolution. Human Nature 18:386-402. [ML]

Malouf, Carling. 1974. The Gosiute Indians. In Shoshone Indians: American Indian ethnohistory: California and Basin-Plateau Indians. Pp. 25-172. New York: Garland.

Marlowe, Frank. 2010. The Hadza: hunter-gatherers of Tanzania. Berkeley: University of California Press.

Marshall, Lorna. 1976. The !Kung of Nyae Nyae. Harvard, MA: Harvard University Press.

Martin, L., and L. Meskell. 2012. Animal figurines from Neolithic Çatalhöyük: figural and faunal perspectives. Cambridge Archaeological Journal 22(3):401419. [DEB-YM]

Mary-Rousselière, G. 1984. Iglulik. In Arctic, vol. 5 of Handbook of North American Indians. D. Damas, ed. Pp. 431-446. Washington, DC: Smithsonian Institution.

McCarthy, Frederick David. 1965. Aborigines: domestic and economic life. In Australian encyclopaedia. Pp. 29-37. Sydney: Grolier.

McClellan, C. 1981. Inland Tlingit. In Subarctic, vol. 6 of Handbook of North American Indians. J. Helm, ed. Pp. 469-480. Washington, DC: Smithsonian Institution.

Mead, Margaret. 1942. Growing up in New Guinea: a study of adolescence and sex in primitive societies. New York: Penguin.

1943. Coming of age in Samoa: a study of adolescence and sex in primitive societies. New York: Penguin.
Meehan, Betty. 1982. Shell bed to shell midden. Canberra: Australian Institute of Aboriginal Studies.

Mellars, Paul. 1996. The Neanderthal legacy: an archaeological perspective from western Europe. Princeton, NJ: Princeton University Press.

2005. The impossible coincidence: a single-species model for the origins of modern human behavior in Europe. Evolutionary Anthropology 14:12-27.

Miller, Maria Dolores. 1983. Changes in the games and pastimes of Australian aborigines. MA thesis, University of California, Santa Barbara.

Milne, S. B. 2005. Palaeo-Eskimo novice flintknapping in the eastern Canadian Arctic. Lournal of Field Archaeology 30(3):329-346. [ML]

Moisés, D. 2003. Expedição conta como brincam os Índios: brinquedos, jogos e brincadeiras. São Paulo: Estado de São Paulo.

Moncel, M.-H. 2003. L'exploration de l'espace et la mobilité des groupes humains au travers des assemblages lithiques a la fin du Pleistocene moyen et au debut du Pleistocene supérieur: la moyenne valle du Rhône entre Drôme et Ardèche. British Archaeological Reports International Series S1184. Oxford: Archaeopress.

Moncel, M.-H., and V. L'Homme. 2007. Les assemblages lithiques des niveaux de Paléolithique moyen del'Abri des Pêcheurs (Ardèche, sud-est de la France): des occupations Néandertaliennes re curantes dans un «fosse». L'Anthropologie 111:211-253.

Morley, Iain. 2009. Ritual and music: parallels and practice, and the Palaeolithic In Becoming human: innovation in prehistoric material and spiritual culture. C. Renfrew and I. Morley, eds. Pp. 159-175. Cambridge: Cambridge University Press.

Mountford, Charles Percy. 1967. Australian Aboriginal portraits. Adelaide: Griffin.

Mouritsen, Flemming, and Jens Qvortrup, eds. 2003. Childhood and children's culture. Odense: University of Southern Denmark Press. [KK]

Myers, J. E. 1978. Cahto. In California, vol. 8 of Handbook of North American Indians. R. F. Heize, ed. Pp. 244-248. Washington, DC: Smithsonian Institute.

Neal, Lana. 2013. The earliest instrument: ritual power and fertility magic of the flute in Upper Paleolithic culture. PhD thesis, University of Texas, Austin.

Nowell, A. 2015a. Children, metaphorical thinking and Upper Paleolithic visual cultures. Childhood in the Past 8(2):122-132.

. 2015b. Learning to see and seeing to learn: children, communities of practice and Pleistocene visual cultures. Cambridge Archaeological Journal 25(4):889-899.

. 2016. Childhood, play and the evolution of cultural capacity in Neanderthals and modern humans. In The nature of culture: based on an interdisciplinary symposium "The Nature of Culture," Tübingen, Germany. M. N. Haidle, N. J. Conard, and M. Bolus, eds. Pp. 87-97. Berlin: Springer. [ML]

Nowell, A., and M. J. White. 2012. Growing up in the Middle Pleistocene: life history strategies and their relationship to Acheulian industries. In Stone tools and the evolution of human cognition. A. Nowell and I. Davidson, eds. Pp. 6782. Boulder: University Press of Colorado. [ML]

Nunes, A. 1999. A sociedade das crianças A'uwe-Xavante: por uma antropologia da criança. Lisbon: Ministério da Educacao.

Olive, M. 1988. Une forme particuliere d'économie de débitage à Étiolles. In Journée d'études technologiques en préhistoire. J. Tixier, ed. Pp. 27-36. Paris: CNRS.

Opler, M. E. 1983. Mescalero Apache. In Southwest, vol. 10 of Handbook of North American Indians. A. Ortiz, ed. Pp. 419-439. Washington, DC: Smithsonian Institution.

Otte, M. 1996. Le Paléolithique inférieur et moyen en Europe. Paris: Armand Colin.

Owens, D'ann, and Brian Hayden. 1997. Prehistoric rites of passage: a comparative study of transegalitarian hunter-gatherers. Iournal of Anthropological Archaeology 16:121-161.

Palacio-Pérez, Eduardo. 2010. Cave art and the theory of art: the origins of the religious interpretation of Palaeolithic graphic expression. Oxford Journal of Archaeology 29:1-14.

Palmer, E. 1883. Notes on some Australian tribes. Journal of the Royal Anthropological Institute 13:276-346.

Parker, Sue Taylor. 1984. Playing for keeps: an evolutionary perspective on human games. In Play in animals and humans. Pp. 271-293. New York: Blackwell.

Pei, W. C. 1931. Notice of the discovery of quartz and other stone artifacts in the Lower Pleistocene hominid-bearing sediments of the Choukoutien cave deposits. Bulletin of the Geological Societv of China 11:109-146.

Pellegrini, Anthony, and Peter K. Smith. 2005. The nature of play: great apes and humans. London: Guilford. 
Peltenburg, Edgar. 1989. The beginnings of religion in Cyprus. In Early societies in Cyprus. E. Peltenburg, ed. Pp. 108-126. Edinburgh: Edinburgh University Press.

Pereira, M. C. S. 1998. Meninas e meninos Kaingáng: o processo de socialização. Londrina, Brazil: Editora Universidade Estadual de Londrina.

Peresani, Marco, Ivana Fiore, Monica Gala, Matteo Romandini, and Antonio Taglizcozzo. 2011. Late Neanderthals and the intentional removal of feathers as evidenced from bird bone taphonomy at Fumane Cave 44 ky B.P., Italy. Proceedings of the National Academy of Sciences of the USA 108:3888-3893.

Peterson, Jean. 1978. The ecology of social boundaries: Agta foragers of the Philippines. Chicago: University of Illinois Press.

Petrie, Constance. 1904. Tom Petrie's reminiscences of early Queensland (dating from 1837). Brisbane: Watson, Ferguson.

Petrie, Helmut. 1980. Pre-initiation stages among Aboriginal groups of north-west Australia. In Aborigines of the West: their past and their present. R. M. Berndt and C. H. Berndt, eds. Pp. 224-233. Perth: University of Western Australia Press.

Pettitt, Paul. 2012. Religion and ritual in the Lower and Middle Palaeolithic. In The Oxford handbook of the archaeology of ritual and religion. T. Insoll, ed. Oxford: Oxford Handbooks Online. doi:10.1093/oxfordhb/9780199232444.013.0022.

Pfeiffer, John. 1982. The creative explosion. Ithaca, NY: Cornell University Press.

Pigeot, N. 1990. Technical and social actors: flintknapping specialists and ap prentices at Magdalenian etoilles. Archaeological Review from Cambridge 91: $126-141$.

Porteus, Stanley David. 1931. The psychology of a primitive people: a study of the Australian Aboriginal. London: Arnold.

Powell, J. V. 1990. Quiluete. In Northwest Coast, vol. 7 of Handbook of North American Indians. Pp. 431-437. Washington, DC: Smithsonian Institution.

Preston, R. J. 1981. East Main Cree. In Subarctic, vol. 6 of Handbook of North American Indians. J. Helm, ed. Pp. 196-207. Washington, DC: Smithsonian Institution.

Radcliffe-Brown, A. R. 1952. Structure and function in primitive society. London: Cohen \& West. [ML]

Ramsey, Jacklyn, and William McGrew. 2005. Object play in great apes: studies in nature and captivity. In The nature of play: great apes and humans. A. D. Pellegrini and P. K. Smith, eds. Pp. 89-112. London: Guilford.

Reilly, P. T. 1966. The sites at Vasey's Paradise. Masterkey 40:126-139.

Riede, F., N. N. Johannsen, A. Högberg, A. Nowell, and M. Lombard. 2018. The role of toys in human cognitive evolution and domain-specific innovation. Evolutionary Anthropology 27:46-59. doi:10.1002/evan.21555. [ML]

Ritzenthaler, R. E. 1978. Southwestern Chippewa. In Northeast, vol. 15 of Handbook of North American Indians. B. G. Trigger, ed. Pp. 743-759. Washington, DC: Smithsonian Institution.

Rivero, Olivia. 2016. Master and apprentice: evidence of learning in Palaeolithic portable art. Journal of Archaeological Science 75:89-100.

Rogersdotter, Elke. 2011. Gaming in Mohenjo-daro: an archaeology of unities. $\mathrm{PhD}$ thesis, University of Gothenburg.

Róheim, Géza. 1974. Children of the desert: the western tribes of Central Australia, vol. 1. New York: Basic.

Roth, Walter. 1902. Games, sports, and amusements. North Queensland Ethnography Bulletin no. 4. Brisbane: Northern Protector of Aboriginals.

Rubel, Paula, and Abraham Rosman. 2001. The collecting passion in America. Zeitschrift für Ethnologie 126(2):313-330. [KK]

Russell, P. 1989. Who and why in Palaeolithic art. Oxford Journal of Archaeology 8:237-249.

Sánchez Romero, Margarita, Eva Alarcón García, and Gonzalo Aranda Jiménez eds. 2015. Children, spaces and identity. Oxford: Oxbow. [KK]

San-Juan, C. 1990. Les matières colorantes dans les collections du musée national de préhistoire des Eyzies. Paleo 2:229-242.

Schapera, Isaac. 1930. The Khoisan peoples of South Africa. London: Routledge.

Schroedl, Alan R. 1977. The Grand Canyon figurine complex. American Antiquity 42:254-265

- 1989. The power and the glory: shamanistic arts of the Archaic period. Canyon Legacy 1:13-17.

Schwartz, Douglas, Arthur Lange, and Raymond deSaussure. 1958. Split-twig figurines in the Grand Canyon. American Antiquity 23:264-274.

Schwartzman, H. B. 1978. Transformations: the anthropology of children's play. New York: Plenum. [GL]

Seaburg, W. R., and J. Miller. 1990. Tillamook. In Northwest, vol. 7 of Handbook of North American Indians. W. Suttles, ed. Pp. 560-567. Washington, DC: Smithsonian Institute.

Sharman, Margaret. 1979. People of the plains, Maasai. Nairobi, Kenya: Evans Brothers.
Sharpe, Kevin, and Leslie Van Gelder. 2006. Evidence for cave marking by Palaeolithic children. Antiquity 80:937-947.

Shea, John. 2006. Child's play: reflections on the invisibility of children in the Palaeolithic record. Evolutionary Anthropology 15(6):212-216.

Sheard, Lauri. 1964. An Australian youth among desert aborigines: journal of an expedition among the aborigines of Australia. Adelaide: Adelaide Libraries Board.

Shelley, P. H. 1990. Variation in lithic assemblages: an experiment. Journal of Field Archaeology 17(2):187-193. [ML]

Shostak, Marjorie. 1976. A !Kung woman's memories of childhood. In Kalahari hunter-gatherers: studies of the !Kung San and their neighbors. R. B. Lee and I. DeVore, eds. Pp. 246-277. Cambridge, MA: Harvard University Press.

. 1981. Nisa: the life and words of a !Kung woman. London: Earthscan.

Silver, S. 1978a. Chimariko. In California, vol. 8 of Handbook of North American Indians. R. F. Heizer, ed. Pp. 205-210. Washington, DC: Smithsonian Institution.

. 1978b. Shastan peoples. In California, vol. 8 of Handbook of North American Indians. R. F. Heizer, ed. Pp. 211-224. Washington, DC: Smithsonian Institution.

Skeates, Robin. 1991. Triton's trumpet: a Neolithic symbol in Italy. Oxford Journal of Archaeology 10(1):17-31.

Skinner, Alanson. 1911. Notes on the eastern Cree and northern Saulteaux. New York: Trustee.

Slaughter, D., and J. Domobrowski. 1989. Cultural continuities and discontinuities: impact on social and pretend play. In The ecological context of children's play. M. N. Block and A. D. Pellegrini, eds. Pp. 282-310. Norwood, NJ: Ablex.

Smith, C. R. 1978. Tubatulabal. In California, vol. 8 of Handbook of North American Indians. R. F. Heizer, ed. Pp. 437-445. Washington, DC: Smithsonian Institution.

Sofaer Derevenski, Joanna. 1994a. Material culture shock: confronting expectations in the material culture of children. In Children and material culture. J. Sofaer Derevenski, ed. Pp. 3-16. London: Routledge.

. 1994b. Where are the children? accessing children in the past. Archaeological Review from Cambridge 13:7-20.

- 1997. Engendering children: engendering archaeology. In Invisible people and processes: writing gender and childhood into European archaeology. J. Moore and E. Scott, eds. Pp. 192-202. London: Taylor \& Francis. - 2000. Children and material culture. London: Routledge.

Soressi, Marie. 2002. Le Moustérien de tradition acheuléenne du sud-ouest de la France: discussion sur la signification du faciès à partir de l'étude comparée de quatre sites: Pech de l'Azé I, le Moustier, la Rochette et la Grotte XVI. Thesis, University of Bordeaux 1.

Soressi, Marie, and Francesco d'Errico. 2007. Pigments, gravures, parures: les comportements symboliques controversés des Néandertaliens. In Les Néandertaliens: biologie et cultures. B. Vandermeersh and B. Maureille, eds. Pp. 297-309. Paris: Éditions du CTHS.

Spencer, R. F. 1984. North Alaska Coast Eskimo. In Arctic, vol. 5 of Handbook of North American Indians. D. Damas, ed. Pp. 320-337. Washington, DC: Smithsonian Institution.

Spencer, William. 1922. Guide to the Australian ethnological collection exhibited at the National Museum of Victoria. Melbourne: Mullett.

Stack, James. 1891. South Island Maori: a sketch of their history and legendary lore. Christchurch: Whitcombe \& Tombs.

Stekelis, Moshé. 1972. The Yarmukian culture of the Neolithic period. Jerusalem: Magnes.

Strehlow, Carl. 1907. Die Aranda und Loritja-stamme in Zentral Australien, vol. 5. Frankfurt: Baer.

Suttles, W., and B. Lane. 1990. Southern Coast Salish. In Northwest Coast, vol. 7 of Handbook of North American Indians. W. Suttles, ed. Pp. 485-502. Washington, DC: Smithsonian Institution.

Sutton, Mary Jo. 2011. In the hand and mind: the intersection of loose parts and imagination in evocative settings for young children. Children, Youth, and Environments 21:408-424.

Sutton-Smith, Brian. 1986. Toys as culture. New York: Gardner.

- 1994. Does play prepare for the future? In Toys, play, and child development. J. H. Goldstein, ed. Pp. 136-146. Cambridge: Cambridge University Press. Swenson, Edward. 2015. The archaeology of ritual. Annual Review of Anthropology 44:329-345.

Talalay, Lauren. 1993. Deities, dolls, and devices: Neolithic figurines from Franchthi Cave, Greece. Bloomington: Indiana University Press.

Thomas, N. W. 1906. Natives of Australia: the native races of the British Empire. London: Constable. 
Thomson, Donald. 1958. The aborigines of Australia. In Australian junior encyclopaedia. P. 13513. Canberra: Australian Institute of Aboriginal and Torres Strait Islanders Studies.

1975. Bindibu country. Melbourne: Nelson.

1983. Children of the wilderness. South Yarra: O’Neil.

Tiller, V. E. 1983. Jicarilla Apache. In Southwest, vol. 10 of Handbook of North American Indians. A. Ortiz, ed. Pp. 440-462. Washington, DC: Smithsonian Institution.

Turnbull, Colin. 1961. The forest people. New York: Simon \& Schuster.

Ucko, Peter, and Andrée Rosenfeld. 1967. Palaeoltihic cave art. New York: McGraw-Hill.

Van Baal, J. 1963. The cult of the bull-roarer in Australia and southern New Guinea. Bijdragen tot de Taal-, Land-, en Volkenkunde 119:201-214.

Van Gelder, Leslie. 2015. Counting the children: the role of children in the production of finger flutings in four Upper Palaeolithic caves. Oxford Journal of Archaeology 34:119-138.

Vanoverbergh, Morice. 1937. Negritos of eastern Luzon. Anthropos 32:905-928.

Wadley, Lyn. 2001. What is cultural modernity? a general view and a South African perspective from Rose Cottage Cave. Cambridge Archaeological Journal 11:201-221.

Walker, Nicholas. 1995. Late Pleistocene and Holocene hunter-gatherers of the Matopos. Studies in African Archaeology 10. Uppsala: Societas Archaeological Upsaliensis.

Wallace, Phyl, and Noel Wallace. 1968. Children of the desert. Melbourne: Nelson.

Wallace, W. J. 1978. Hupa, Chilula, and Whilkut. In California, vol. 8 of Handbook of North American Indians. R. F. Heizer, ed. Pp. 164-179. Washington, DC: Smithsonian Institution.

Wannenburgh, Alf. 1979. The Bushman. Singapore: Tien Wah.

Wardle, D., and K. A. Wardle. 2007. The child's cache at Assures Toumba Macedonia. In Children, childhood, and society. British Archaeological Reports,
International Series 1696. S. Crawford and G. Shepard, eds. Pp. 29-44. Oxford: Archaeopress.

Warner, William. 1937. A black civilization: a social study of an Australian tribe. New York: Harper.

Watts, Ian, Michael Chazan, and Jayne Wilkins. 2016. Early evidence for brilliant ritualized display: specularite use in the Northern Cape (South Africa) between $\sim 500$ and $~ 300$ ka. Current Anthropology 57:287-310.

Whitley, M. 1929. Children's interest in collecting. Journal of Educational Psychology 20:249-261.

Wiley, A. 1985. The reaction against analogy. Advances in Archaeological Method and Theory 8:63-111.

Witherspoon, G. 1983. Navajo social organization. In Southwest, vol. 10 of Handbook of North American Indians. A. Ortiz, ed. Pp. 524-535. Washington, DC: Smithsonian Institution.

Wobst, Hans Martin. 1974. Boundary conditions for Palaeolithic social systems: a simulation approach. American Antiquity 39:147-178.

Woodburn, James. 1970. Hunters and gatherers: the material culture of the nomadic Hadza. London: British Museum.

Worsley, Peter. 1954. Material symbols of the human beings among the Wanindiljaugwa. Man 261:165-167.

Wreschner, E. E. 1976. The potential significance of the pebbles with incisions and cupmarks from the Yarmukian of Sha'ar Hagolan, Israel. Bulletin de la Société Royal Belge d'Anthropologie et de Préhistoire 87:157-165.

Zigmond, M. L. 1986. Kawaiisu. In Great Basin, vol. 11 of Handbook of North American Indians. W. L. d'Azevedo, ed. Pp. 398-411. Washington, DC: Smithsonian Institution.

Zilhão, João. 2005. Burial evidence for the social differentiation of age classes in the early Upper Paleolithic. In Comportements des hommes du Paléolithique moyen et supérieur en Europe: territories et milieux. D. Vialou, J. RenaultMiskovsky, and M. Patou-Mathis, eds. Pp. 231-241. Paris: CNRS.

This content downloaded from 130.056.097.188 on February 14, 2019 18:39:34 PM 